By

Paul D. Cohn and Clarence H. Bloomster

July 1976

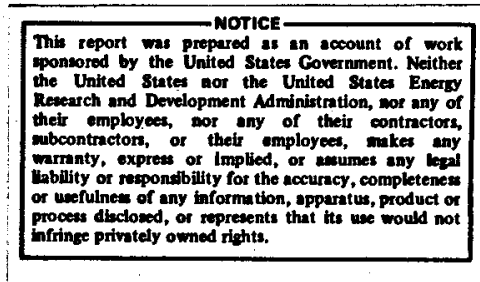

Battelle

Pacific Northwest Laboratories

Richland, Washington 99352 


\section{DISCLAIMER}

This report was prepared as an account of work sponsored by an agency of the United States Government. Neither the United States Government nor any agency Thereof, nor any of their employees, makes any warranty, express or implied, or assumes any legal liability or responsibility for the accuracy, completeness, or usefulness of any information, apparatus, product, or process disclosed, or represents that its use would not infringe privately owned rights. Reference herein to any specific commercial product, process, or service by trade name, trademark, manufacturer, or otherwise does not necessarily constitute or imply its endorsement, recommendation, or favoring by the United States Government or any agency thereof. The views and opinions of authors expressed herein do not necessarily state or reflect those of the United States Government or any agency thereof. 


\section{DISCLAIMER}

Portions of this document may be illegible in electronic image products. Images are produced from the best available original document. 


\title{
CAPITAL COST MODELS FOR \\ GEOTHERMAL POWER PLANTS
}

by

Paul D. Cohn*

and

C. H. Bloomster

\begin{abstract}
A computer code, titled GEOCOST, has been developed at Battelle, Pacific Northwest Laboratories, to rapidly and systematically calculate the potential costs of geothermal power. This report provides a description of the cost models in GEOCOST for the geothermal power plants. Plant cost models include the flashed steam and binary systems. The data sources are described, along with the cost data correlations, resulting equations, and uncertainties. Comparison among GEOCOST plant cost estimates and recent A-E estimates are presented. The models are intended to predict plant costs for second and third generation units, rather than the more expensive first-of-a-kind units.
\end{abstract}

\section{ACKNOWLEDGMENTS}

The authors appreciate the contributions made to this report by the following BNW staff members: H. D. Huber, R. A. Walter, and C. A. Knutsen.

*Consultant for Plant Cost Analysis. Contract BCA-947, Energy Engineering Associates. Prepared for: U.S. Energy Research and Development Administration PNL Geothermal Economic and Benefit cost Subprogram. 
ABSTRACT

ACKNOWLEDGMENTS

LIST OF TABLES .

LIST OF FIGURES

1.0. INTRODUCTION .

2.0 SUMMARY

3.0 FLASH PLANT

3.1 Power Plant Costs

3.1.1 Total Power Plant cost . . . . . . . . . . . 3

3.1.2 Piping and Insulation . . . . . . . . . . 3

3.1.3 Turbogenerator costs . . . . . . . . . 3

3.1.4 Miscellaneous Support Equipment . . . . . . . 3

3.1.5 Instrumentation and Controllers . . . . . . . . 3

3.1.6 Electrical Support Equipment . . . . . . . . 8

3.1.6.1 Electric Motor Pumped Systems and

3.1.6.2 Turbine Pumped Systems . . . . . . . 8

3.1 .7 Condenser . . . . . . . . . . . . . . 8

3.1.8 Installation Testing . . . . . . . . . . . 9

3.1.9 Buildings, Foundations, and Support Equipment . . . 9

3.1.10 Plant Crane . . . . . . . . . . . . . . 9

3.1.11 Gas Ejectors (Steam Driven) . . . . . . . . . 9

3.1 .12 Pumps . . . . . . . . . . . . . . . . 14

3.1.13 Heat Rejection Systems . . . . . . . . . 14

3.1.14 Switchyard . . . . . . . . . . . . 14

3.1.15 0ther Costs . . . . . . . . . . . . . 18

3.1 .16 Cost Correlations . . . . . . . . . . . . 18

4.0 BINARY PLANT . . . . . . . . . . . . . . . 23

4.1 Binary Power Plant Costs . . . . . . . . . . 23

4.1.1 Piping, Insulation, and Tanks . . . . . . . . 23

4.1.2 Plant Crane . . . . . . . . . . . . 24

4.1.3 Turbogenerator . . . . . . . . . . . 24 
4.1.4 Vapor Generator, Auxiliary Heat Exchangers, Desuperheater, and Condenser. .. . . . . . 24

4.1.5 Miscellaneous Support Equipment . . . . . . . . 24

4.1.6 Instrumentation and Controllers . . . . . . . . 24

4.1.7 Electrical Support Equipment . . . . • • • • 29

4.1.8 Installation Testing . . . . . . . . . . . 29

4.1.9 Buildings, Structures, and Foundations . . . . . 29

4.1.10 Binary Fluid Pumps . . . . . . . . . . . . 29

4.1.11 Reinjection Pumps (Geothermal Fluid) . . . . . 29

4.1.12 Cooling Towers . . . . . . . . . . . . . 29

5.0 CAPITAL COST COMPARISONS . . . . . . . . . . . . 36

5.1 Detailed Evaluation . . . . . . . . . . . . 38

5.1.1 Aerojet Nuclear, 15 MWe, 2 Flash Plant . . . . . 38

5.1.2 LBL, 10 MWe, Binary Isobutane Plant . . . . . ., 41

5.1.3 TRW, 10 MWe, Binary Isobutane Plant . . . . . . 44

5.1.4 Bechtel Binary Geothermal Power Plant. . . . . . 46

5.1.5 Comparison of Binary Plant Cost Versus Power Leve]. . 48 6.0 CONCLUSION . . . . . . . . . . . . . . . . . 52 REFERENCES . . . . . . . . . . . . . . . . . . . 55 
1-1. Cost Indices for Normalizing Prior Year Costs to Year End 1975 Dollars . . . . . . . . . . . . . . . 1

3-1. Flash Steam Power Plant Capital Cost Coefficients . . . . . 20

3-2. Cost Factors for Instrumentation and Controllers . . . . . 22

3-3. Cost Factors for Electrical Support Equipment . . . . . . 22

4-1. Binary Power Plant Capital Cost Coefficients . . . . . . 32

4-2. Cost Factors for Instrumentation and Controllers . . . . . 34

4-3. Cost Factors for Electrical Support Equipment . . . . . . 34

4-4. Heat Exchanger cost Equations . . . . . . . . . . . 35

5-1. Comparison of Idaho Falls and GEOCOST F.lash Plant Capital Costs . . . . . . . . . . . . . . . . . . 39

5-2. Comparison of LBL Binary and GEOCOST Plant Capital Cost . . . 42

5-3. Cost Comparison for Dry Cooling Tower Installation . . . . 44

5-4. Comparison of TRW and GEOCOST Binary Plant Capital Cost Estimates . . . . . . . . . . . . . . . 45

5-5. Comparison of Bechtel and GEOCOST Binary Plant Capital Cost Estimates . . . . . . . . . . . . . . . . 47

5-6. Comparison of GEOCOST and A-E Cost Estimates--A-E Estimates as a \% of GEOCOST Estimates .. . . . . . . . . . . . 51 


\section{LIST OF FIGURES}

Page

3.1-1. Installed Steam Plant Cost . . . . . . . . . . . 44

3.1-2. Installed Flash Plant Piping and Insulation cost for Carbon and Stainless Steel Systems Using Motor Driven or Turbine Pumps. Installed cost versus volume steam flow rate... . . . . . . . . . . . . 5

3.1-3. Flash Plant Installed Cost Turbine Generator, $\$ 10^{6}$

Versus Plant Power, MWe . . . . . . . . . . . . 6

3.1-4. Miscellaneous Support Equipment Installed Cost, $\$ 10^{3}$ Versus Plant Power, MWe . . . . . . . . . . . . . 7

3.1-5. Installed Cost - Flash Plant Condenser, $\$ 10^{3}$ Versus Condenser Steam Rate, $10^{6} \mathrm{lbm} / \mathrm{hr}$. . . . . . . . . 10

3.1-6. Flash Plant Buildings, Foundations, and Support Equipment Installed Cost, \$106 Versus Plant Power, MWe . . . . . 11

3.1-7. Crane, Flash Plant Installed Cost, $\$ 10^{5}$ Versus Plant Power, MWe . . . . . . . . . . . . . . 12

3.1-8. Steam Driven Gas Ejector - Installed Cost, $\$ 10^{3}$ Versus Ejected Gas Volume, CFM . . . . . . . . . . . . 13

3.1-9. Installed Flash Plant Water Service Pumps--Carbon and Stainiess Steel Pumps Using Motor or Turbine Drives-Installed Cost Versus Total Steam Flow Rate . . . . . . 15

3.1-10. Flash Plant Wet Cooling Tower - Installed Cost, $\$ 10^{6}$

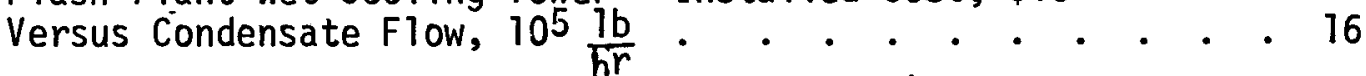

3.1-11. Dry Cooling Tower (Direct Contact Condenser) Installed Cost $\$ 10^{6}$ Versus Heat Rejected, $10^{9} \mathrm{Btu} / \mathrm{hr}$. . . . . . 17

3.1-12. Switchyard - Installed Cost, $\$ 10^{5}$ Versus Plant Power, MWe. . 19

4.1-1. Binary Plant Installed Cost--Piping, Insulation, and Tanks for Carbon and Stainless Steel Systems, Using Motor Driven or Turbine Driven Pumps--Installed Cost Versus Boiler Exit

4.1-2. Binary Plant Turbogenerator - Installed Cost, $\$ 10^{3}$ Versus Working Fluid Flow Rate, $10^{3} \mathrm{lb} / \mathrm{hr}$. . . . . . . 26

4.1-3. Binary Plant Installation Testing Cost, Versus Plant Power, MWe . . . . . . . . . . . . . . . . . 27

4.1-4. Installed Cost for Binary Plant Buildings, Structures, and Foundations... . . . . . . . . . . . . . . 28

4.1-5. Binary Plant Installed Pump Costs, Carbon Steel . . . . . 30

5.1-1. Comparison of GEOCOST and A-E Cost Estimates - Binary Plant Power Plants 


\section{CAPITAL COST MODELS FOR GEOTHERMAL POWER PLANTS}

\subsection{INTRODUCTION}

This report provides a description of data source, cost correlations, and resulting economic models for the Flash and Binary geothermal power plants. This report covers the costs specifically associated with the power plant, heat rejection system, and the switchyard. Equipment cost data were gathered primarily from three sources: industry vendors, independent A-E evaluation, and operators of geothermal power plants. Much of the equipment cost data were pre-1975 and these were updated to end of 1975 costs. Difficulty was experienced in obtaining some vendor equipment costs due to the changing nature of the capital equipment business, the specialized requirements of the geothermal systems, and the rapidly fluctuating price picture. The cost models presented in this report are included in the GEOCOST computer programs $(1-1,1-2,1-3)$.

Cost indices were used to normalize equipment and plant component costs to end of year 1975 prices. References 1-4 and 1-5 provided bases for escalating costs as shown in Table 1-1. This table was used for equipment and plant component items discussed in the following sections.

\begin{tabular}{|c|c|c|c|c|c|c|c|c|c|}
\hline & & & & & & & & & \\
\hline Eal & 1904 & 1966 & 1968 & 1968 & $19 / 0$ & 1972 & 1913 & 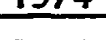 & $19 / 5$ \\
\hline Index & 2.17 & 2.02 & 2.02 & 1.94 & 1.70 & 1.50 & 1.40 & 1.18 & 1.00 \\
\hline
\end{tabular}

\subsection{SUMMARY}

Total power plant and installed equipment cost correlations (in 1975 \$) were prepared by analyzing cost data for major plant components. Plant costs were correlated primarily as a function of power level and/or steam or working fluid flow rates. Estimates for total plant costs, as synthesized from the individual cost equations, correlated well with (1) data for established geothermal plants, and (2) recent A-E estimates for geothermal power installations. The latter comparisons are discussed in detail in Section 5 of this 
report. The dependence of plant component costs as a function of steam or working fluid mass flow rates provides the sensitivity of plant costs to the variations in geothermal fluid thermal conditions.

\subsection{FLASH PLANT}

The Flash Plant uses the geothermal energy in the following modes:

(1) Steam flashed and separated (single flash cycle) at the wellhead,

(2) Fluid transmitted to the piant and flashed and separated (single flash cycle) at the plant site, and (3) Multiple flash combinations of options (1) and (2). These various options are built into the GEOCOST computer mode1. $(1-1)$

\subsection{Power Plant Costs}

Costs for various plant components and plant equipment items on an installed basis, were accumulated from vendors, an independent A-E analysis, (a) and data published for operating and proposed geothermal plants, References 3-1 through -20 . Much of the steam plant data came from the Pacific Gas and Electric Company submittals to the California Public Utilities Commission. Many of the references include equipment cost data reported in various ways, including sharing of common equipment, so that some sorting and exclusion of data was required to provide correlatable results from common bases. Table 3-1, at the end of this chapter, lists the correlations obtained for the Geothermal Flash Plant components.

\footnotetext{
(a) Analysis of existing and proposed power plant component cost data (for both Binary and Flash Plants) revealed that large uncertainties exist for certain component costs. Therefore, a study was conducted with Vitro Engineering to provide improved cost estimates for these components. Nine different components were analyzed by Vitro; the results of their component cost analyses are presented throughout this report. Stainless and/or carbon steel systems using electrical or turbine driven pumps are costed. The variations in costs due to pump type selection are also reflected in the costs of instrumentation and controllers, and electric support equipment. The effect of the Vitro study raised the Flash Plant costs about $5 \%$ over previous estimates and raised the binary plant cost about $20 \%$ over previous estimates.
} 


\subsubsection{Total Power Plant Cost}

Figure 3.1.1 provides total power plant costs for existing and proposed geothermal steam power plants, excluding the field and transmission portions. The equation developed from the plant cost data is used as a checking tool to compare this generalized model to geothermal plant costs synthesized from the various cost equations. Further, the correlation provides an accurate prediction for "conventional" dry steam geothermal plant costs.

\subsubsection{Piping and Insulation}

The equations for these components (Figure 3.1-2) were developed from the Vitro study (Ref. 3-14). They provide cost information for carbon and stainless steel piping using turbine and electric motor pumped systems. The cost is correlated as a function of total flashed steam flow, on a volume basis, exiting from the flasher(s). This independent variable was selected since steam piping dominate the plant piping cost.

\subsubsection{Turbogenerator Costs}

Turbogenerator costs (Figure 3.1-3 and Table 3-1) correlated best with a combined equation which includes both steam flow and power level. This seems reasonable based on the primary cost dependence of the generator on power level and the combined dependence of the turbine on both steam flow and power. The cost of the $N$ (Hanford) reactor (low pressure) turbine generators at 430 MWe each was included in this correlation. None of the plant data permitted separation of the turbine and generator cost information.

\subsubsection{Miscellaneous Support Equipment}

Miscellaneous support equipment includes steam separators (at the plant site), mufflers, steam scrubbers, minor heat exchangers, tanks, and other nonspecified steam plant process support equipment. The data and correlation are shown in Figure 3.1-4.

\subsubsection{Instrumentation and Controllers}

The correlation for these components was obtained from the Vitro study, Reference 3-14. The costs for instrumentation and controllers are developed as percentage multipliers of the other equipment costs. No specific 


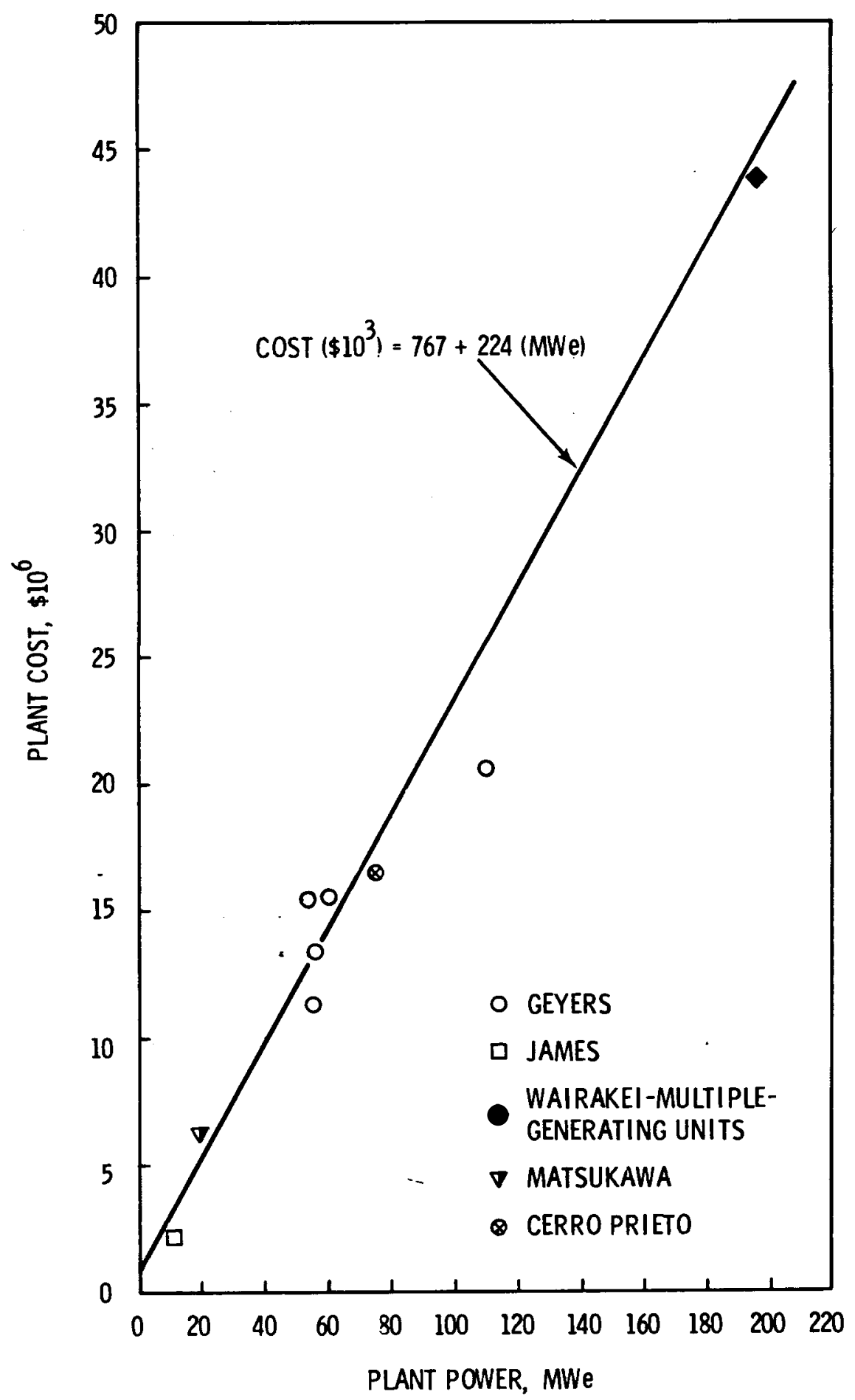

FIGURE 3.1-1. Installed Steam Plant cost (W/o Field or Transmission) Versus Plant Power, MWe 


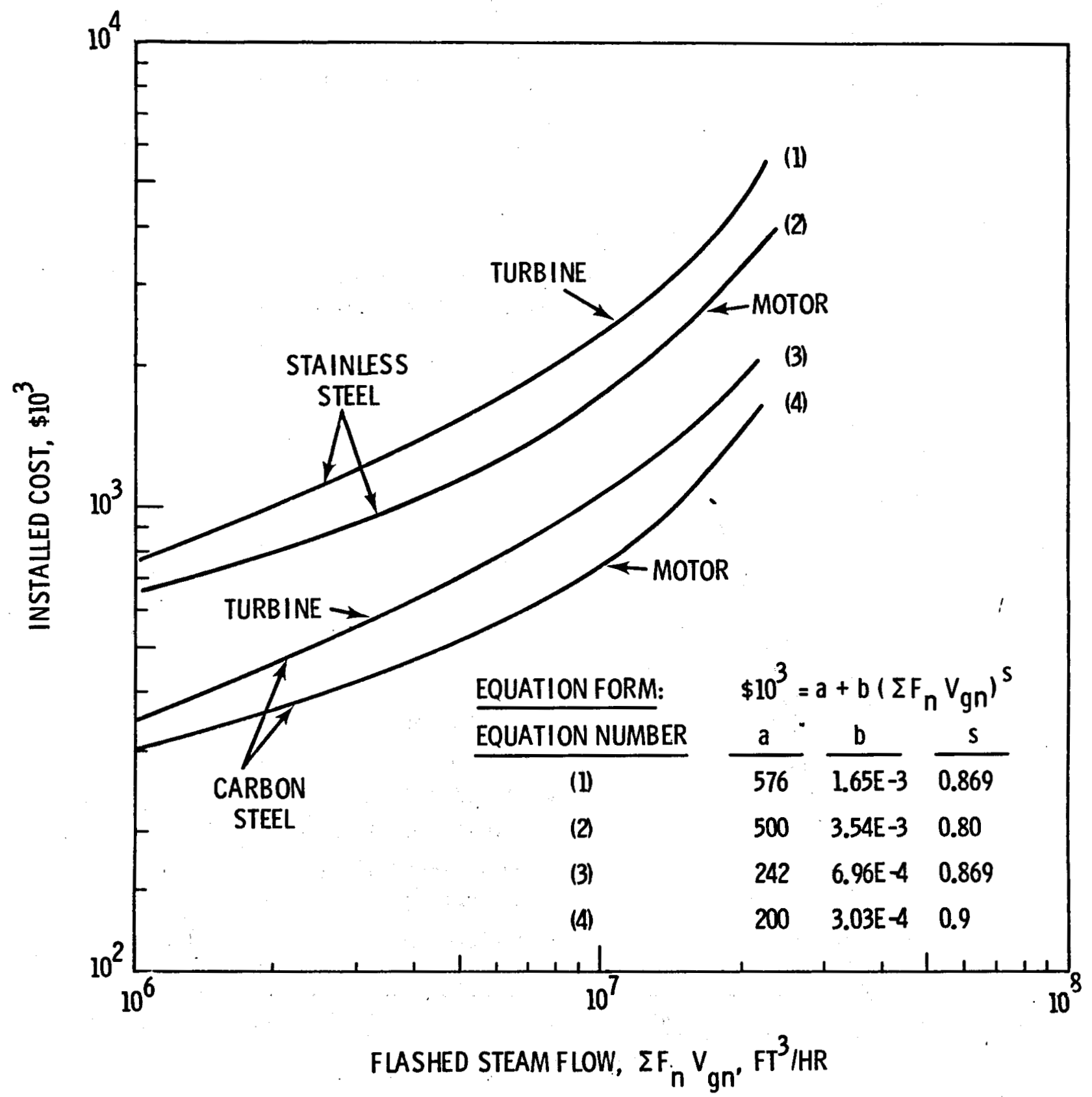

FIGURE 3.1-2. Installed Flash Plant Piping and Insulation Cost for Carbon and Stainless Steel Systems Using Motor Driven or Turbine Pumps. Installed cost versus volume steam flow rate. 


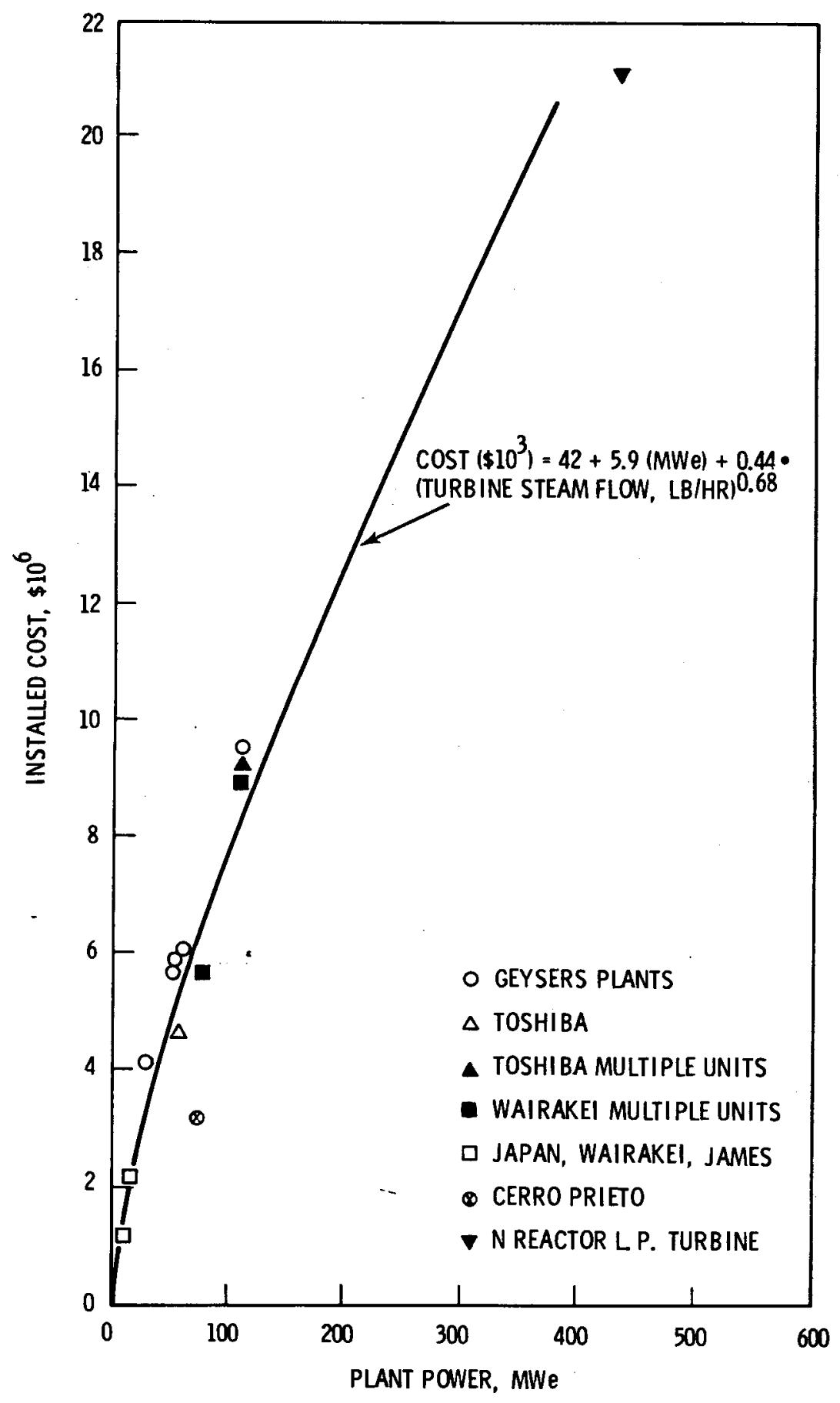

FIGURE 3.1-3. Flash Plant Installed Cost Turbine Generator, $\$ 10^{6}$ Versus Plant Power, MWe 


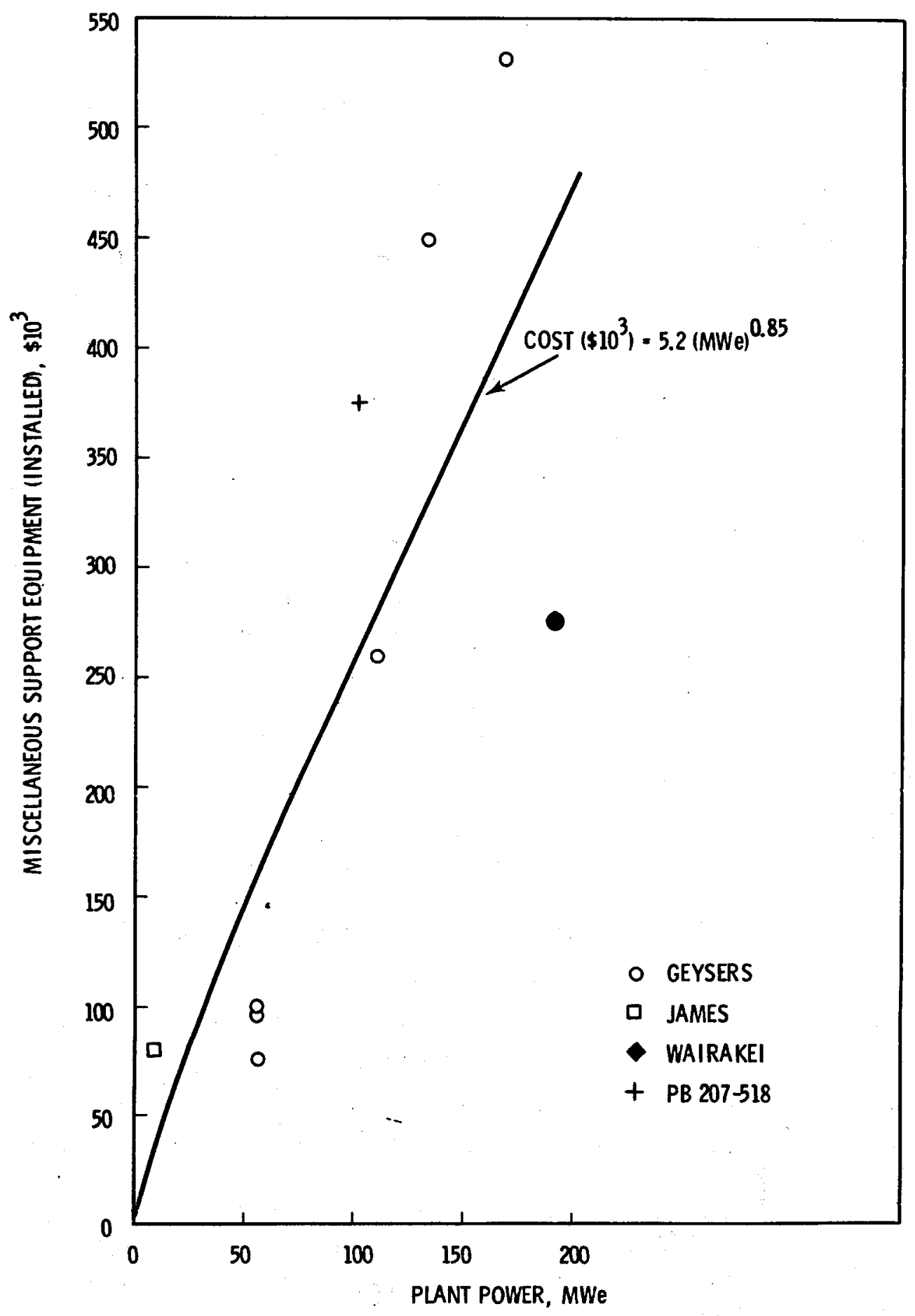

FIGURE 3:1-4. Miscellaneous Support Equipment Installed Cost, $\$ 10^{3}$ Versus Plant Power, MWe 
quotes could be obtained from vendors for existing geothermal plants. Operating geothermal plants did not specify costs separately for instrumentation and controllers. The percentage multipliers for I\&C costs are listed in Table 3-2. Instrumentation and controller costs depend upon both equipment cost and the type of pumping system used, as may be seen in Table 3-2. The capital expence for Instrumentation and Controllers for turbine pumped systems comes out higher than for electrically pumped systems. Conversely, the electrical support equipment for the (electric) motor pumped systems is considerably higher than the turbine pumped systems, (See Section 3.1.6).

\subsubsection{Electrical Support Equipment}

The cost for this equipment, developed from the Vitro study, (3-14) is applied as percentages of the capital cost of the various components. This item includes the majority of electrical equipment in the generating plant with the exception of the turbogenerator and building service power. Electrical support equipment includes operating switchgear, panels, transformers, and wiring. The percentage multipliers for this equipment is shown in Table 3-3.

\subsubsection{Electric Motor Pumped Systems and 3.1.6.2 Turbine Pumped Systems}

Utility-operator cost data were available for electrically pumped system and not available for turbine pumped systems. The Vitro study, provided percentage multipliers for electrical support equipment cost as a function of other equipment cost. Electrical support equipment costs are considerably lower for turbine pumped systems, as would be expected. The cost data for these items is shown in Table 3-3, and includes essentially the same equipment cited in 3.1.6, above.

\subsubsection{Condenser}

Two types of condensers were investigated for cost: barometric spray and indirect condensers. Data for spray condensers were supplied by Ingersol1 Rand and indirect condensers by Southwest Engineering. Only F.0.B. costs were obtained; total installed costs were estimated by the vendors at from 2 to 3 times base hardware costs. A factor of 3 was 
selected for the installed cost basis. An additional data point was obtained (Reference 3-9) for the fixed cost (zero) intercept of central station plant condensers. The data and correlation are shown in Figure 3.1-5.

\subsubsection{Installation Testing}

This item is treated as a capital expense since it is performed by the power plant supplier prior to turning over the plant to the utility operator. This estimated cost is shown in equational form in Table 3-1. (The data source is obtained from the binary plant information. (4-2) Current A-E estimates for geothermal power plants do not show this item as a separate expense, consequently it is treated as an option in the cost summary.

\subsubsection{Buildings, Foundations, and Support Equipment}

This category includes the civil structures and works, utility support equipment, and personnel oriented service equipment. Considerable data were available for this category. However, various utilities and authors include different items within this classification; this results in considerable data scatter. Site dependence is another reason for the data scatter. The correlation based on these data is shown in Figure 3.1-6.

\subsubsection{Plant Crane}

The installed cost correlation of this item is shown in Figure 3.1-7. Utility and industry vendor estimates were used for the correlation. The heaviest item for crane requirements in the steam plant is usually the generator. This component was the determining factor for the geothermal plant cranes.

\subsubsection{Gas Ejectors (Steam Driven)}

Several different types of gas ejectors were examined for possible plant use. Steam driven gas ejectors, now widely used in geothermal plants, were selected for the flash plant. The cost correlation for the steam driven gas ejector is shown in Figure 3.1-8. 


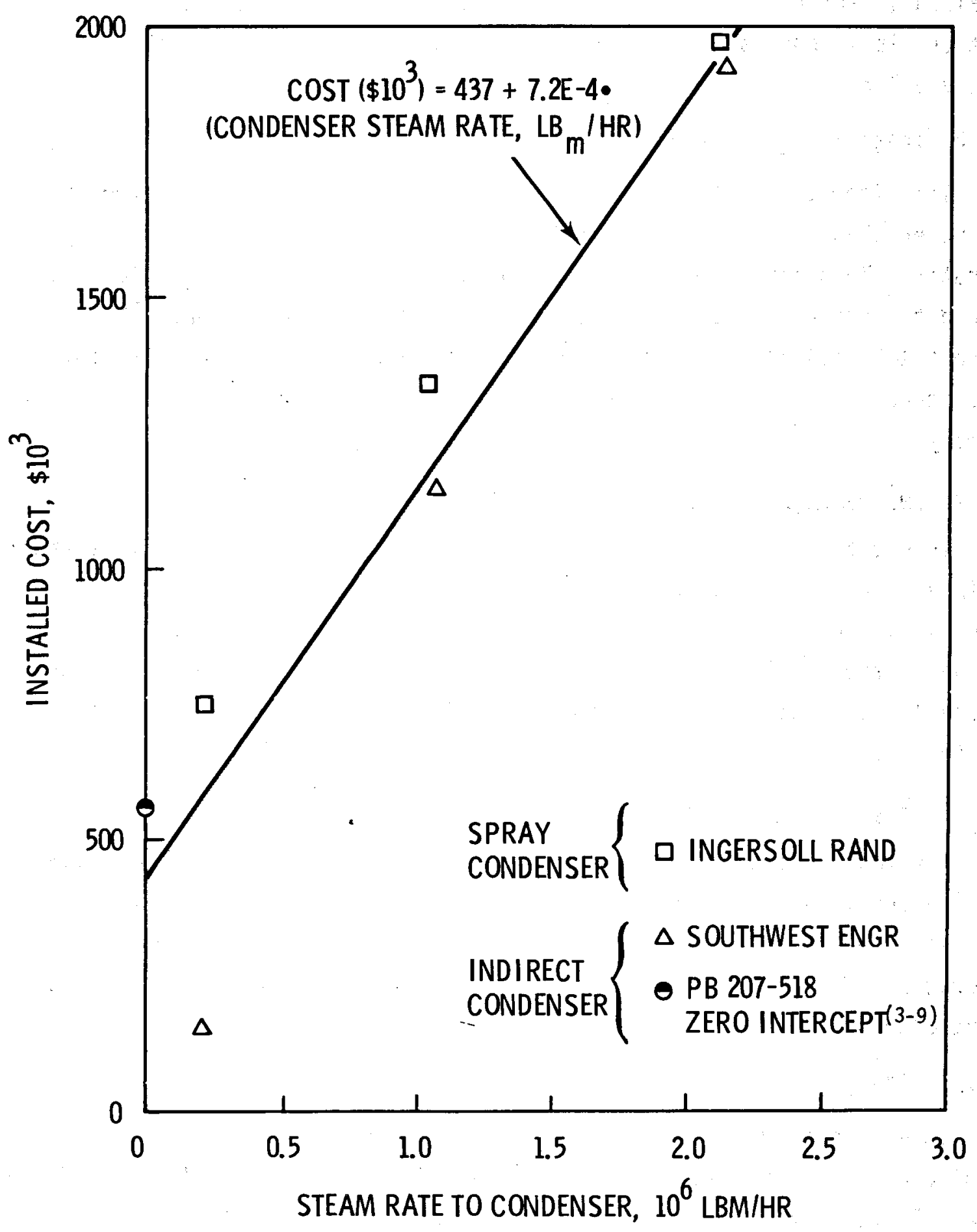

FIGURE 3.1-5. Installed Cost - Flash Plant Condenser, $\$ 10^{3}$ Versus Condenser Steam Rate, $10^{6} 1 \mathrm{bm} / \mathrm{hr}$ 


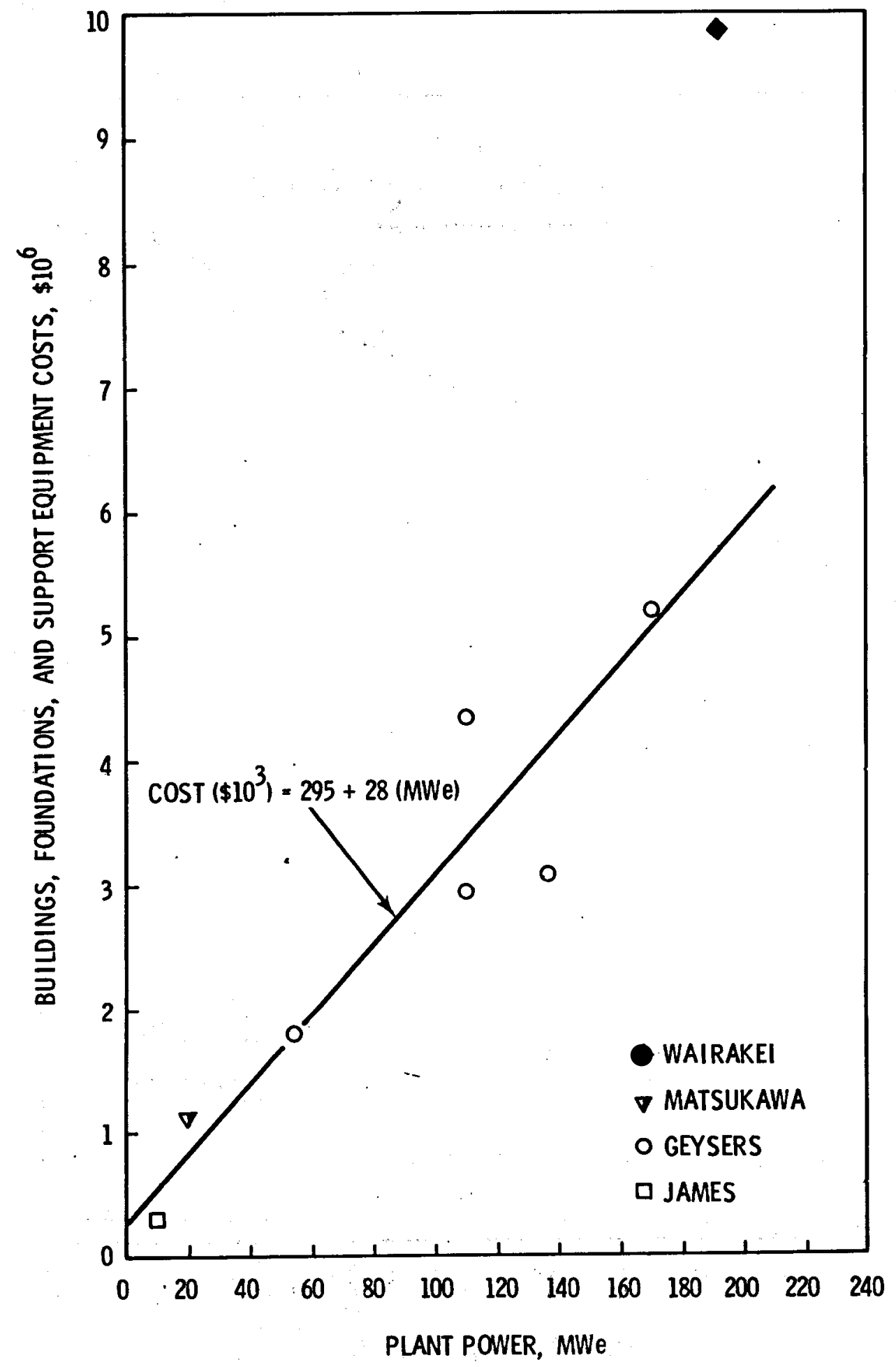

FIGURE 3:1-6. Flash Plant Buildings, Foundations, and Support Equipment Installed Cost, $\$ 10^{6}$ Versus Plant Power, MWe 


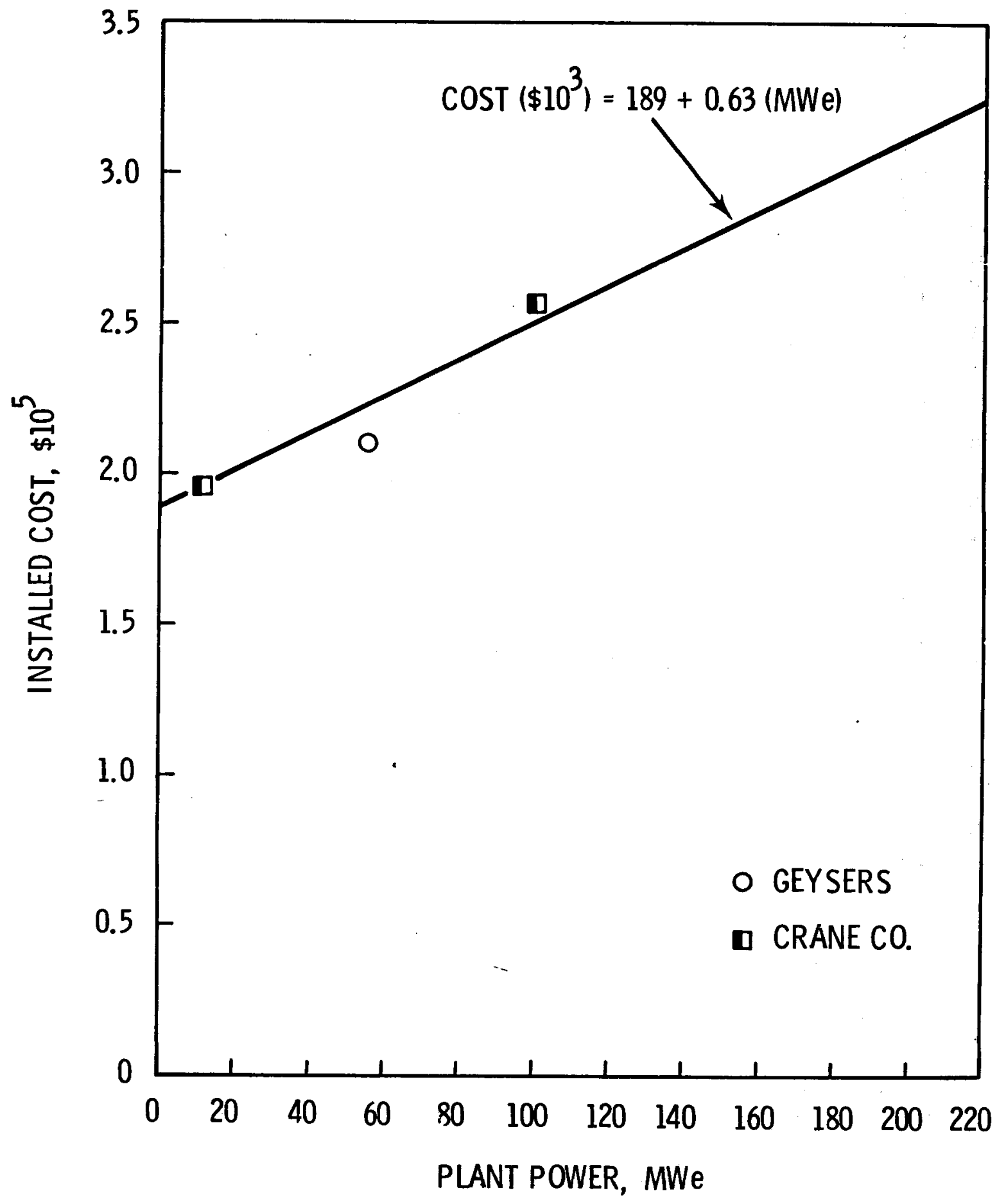

FIGURE 3:1-7. Crane, Flash Plant Installed Cost, $\$ 10^{5}$ Versus Plant Power, MWe 


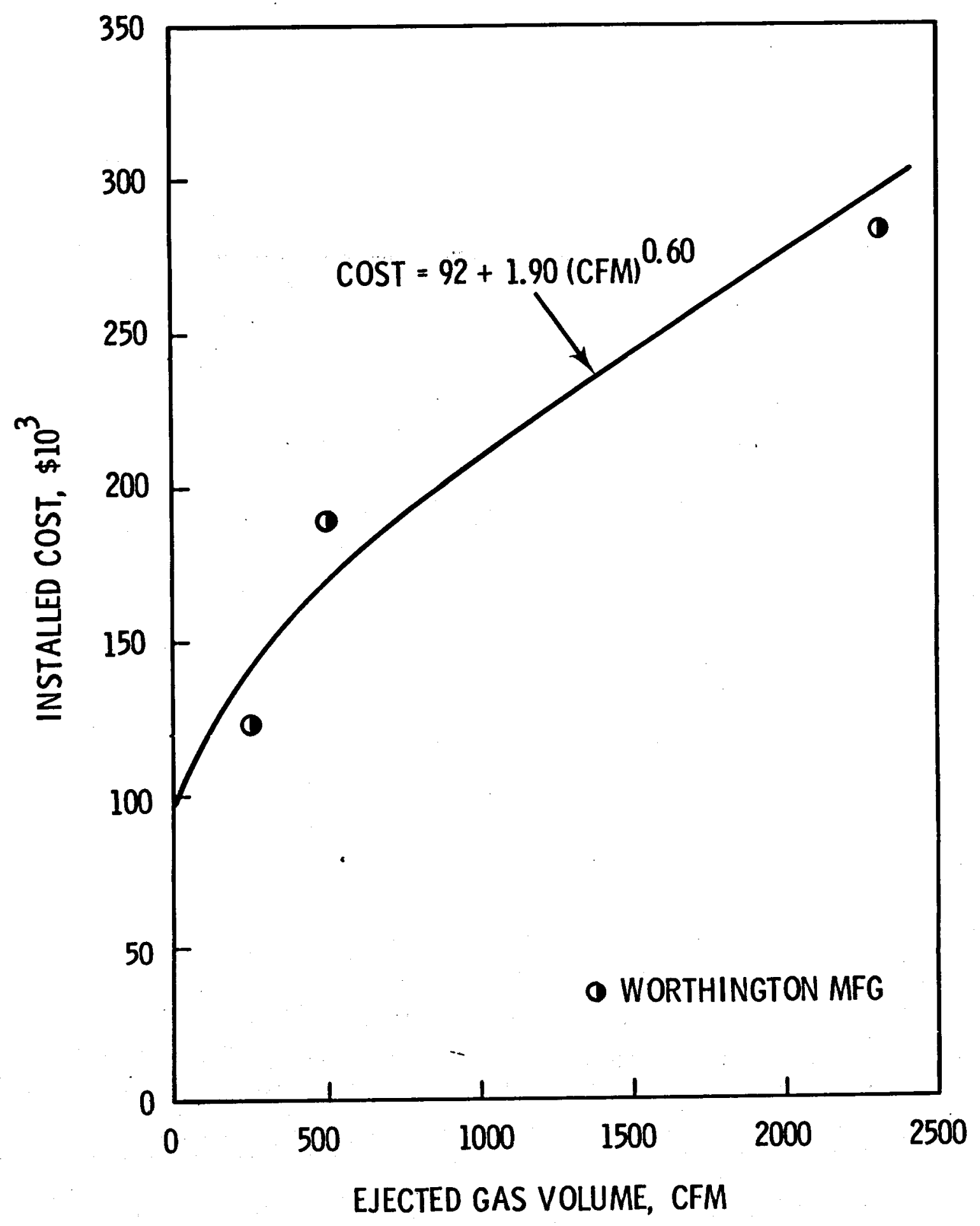

FIGURE 3.1-8. Steam Driven Gas Ejector - Installed Cost, $\$ 10^{3}$ Versus Ejected Gas Volume, CFM 
Vacuum pumps were not considered due to the high pumping requirements for water vapor carry-over.* Some of the Geysers plants use waterdriven aspirator gas ejectors: However, a hillside or a gravity feed location for the reinjection well and plant condenser, plus an adequate supply of water at a temperature less than about $110^{\circ} \mathrm{F}$, are required. Costs could not be obtained for the aspirator installation; and, due to its specialized requirements, the aspirator ejector was not included in the GEOCOST model.

\section{1 .12 Pumps}

The cost of pumps for the geothermal power plant varies widely, depending on the pumping requirements, the use of materials, and pumps drives. The Vitro study, Reference 3-14, provided a detailed cost breakdown of pump costs using stainless or carbon steel with electric or turbine drives. Table 3-1 1ists these cost equations and Figure 3.1-9 depicts the cost correlations in graphical form.

\subsubsection{Heat Rejection Systems}

Two cooling mode options are available in GEOCOST: wet or dry forced draft cooling towers. The correlations for the two cooling methods are shown in Figures 3.1-10 and -11 . Vendor, A-E, and journal article data were used for the correlations. More accurate cost data correlations can be obtained by correlating "Tower Unit" data rather than the condensate flow for the wet tower or heat load for the dry tower. The Marley study, Reference $3-15$, shows that the accuracy is improved from $\pm 20 \%$ to $\pm 12 \%$ when Tower Unit data are used. However, the Tower Unit computation requires data listings beyond the current scope of GEOCOST. The more accurate Tower Unit method will be included in an updated version of GEOCOST. The present cost correlations are shown in Table 3-1.

\subsubsection{Switchyard}

Two components usually make up the switchyard costs: the main switchyard at the plant and the line station at the junction with the utility's

* Water vapor carry-over can be reduced by condensate chilling, but at additional plant capital and operating costs. 


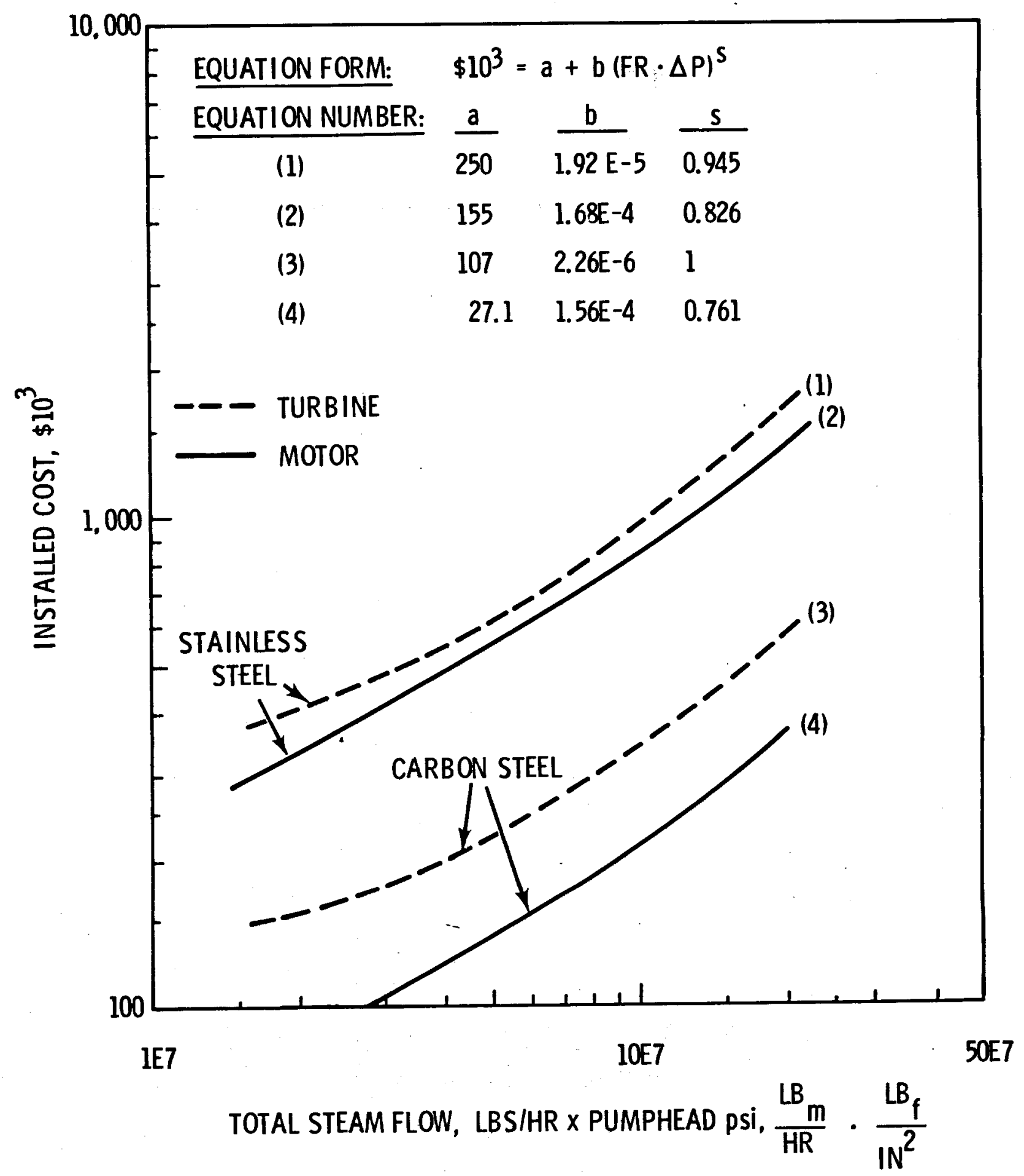

FIGURE 3.1-9. Installed Flash Plant Water Service Pumps-Carbon and Stainless Steel Pumps Using Motor or Turbine Drives--Installed Cost Versus Total Steam Flow Rate 


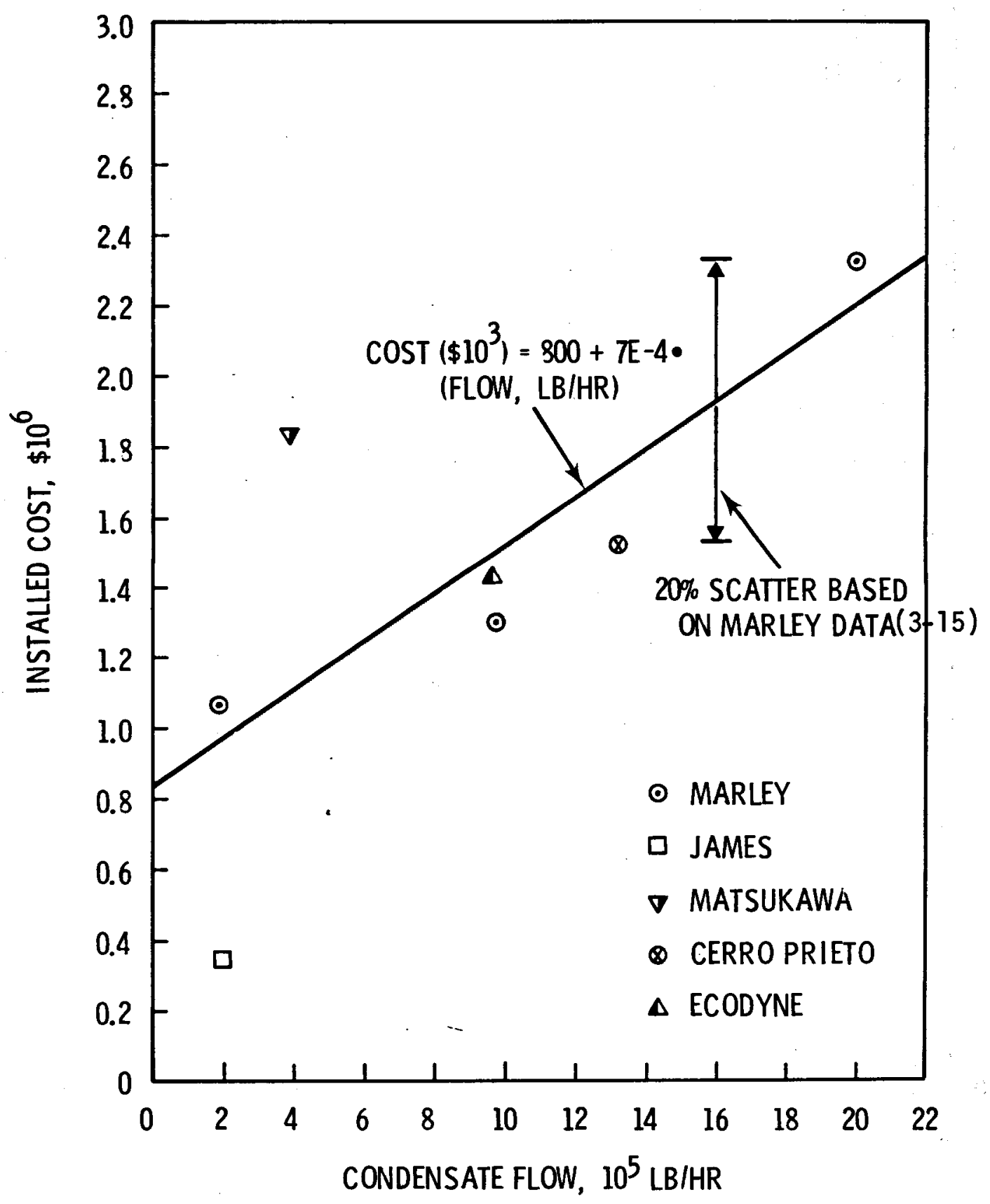

FIGURE 3.1-10. Flash Plant Wet Cooling Tower - Installed Cost, $\$ 10^{6}$ Versus Condensate Flow, $10^{5} \frac{\mathrm{lb}}{\mathrm{hr}}$ 


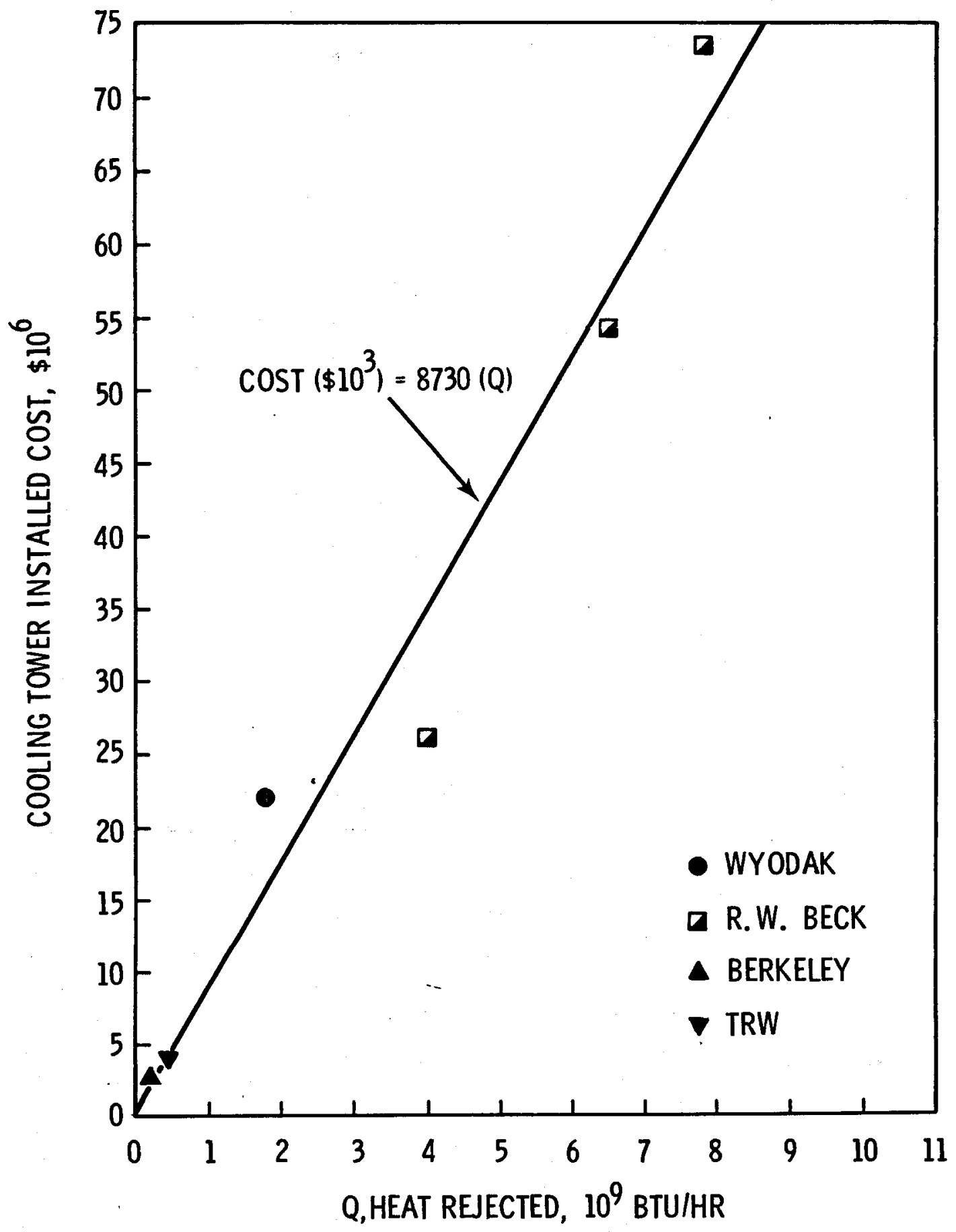

FIGURE 3.1-11. Dry Cooling Tower (Direct Contact Condenser) Installed Cost $\$ 10^{6}$ Versus Heat Rejected, $10^{9} \mathrm{Btu} / \mathrm{hr}$ 
main grid. Figure 3.1-12 provides the cost correlation. Utility operators are the source of these data as indicated.

\subsubsection{Other Costs}

Two general costs are incurred as part of any plant installation. These include the Engineering and Design costs, and the Administration and Indirect costs. Reference 3-9 provides cost correlations for these items. These were used directly for the geothermal plants. Engineering and Design Costs are estimated at $10 \%$ of the installed plant hardware cost; Administration and Indirect costs are estimated at $8 \%$ of these costs.

A contingency cost is not included in the total plant cost. A $10 \%$ contigency was recommended in the Vitro study ${ }^{(3-14)}$ as a lower limit for multiple units of "identical type." A contingency factor is usually added in most $A-E$ estimates.

\subsubsection{Cost Correlations}

Table 3-1 provides a listing of the cost data correlations and curve fitted equations. The equations were determined by the use of NELLY code. ${ }^{(3-21)}$ The standard equational form used is cost $\left(\$ 10^{3}\right)=a+b(x)^{s}$, where $a, b$, and $s$ are coefficients reflecting fixed costs (a); materials, equipment and installation (b); and size scale ( $s$ ). Cost is in year-end 1975 dollars and $x$ is the independent variable(s) as specified in the table. 

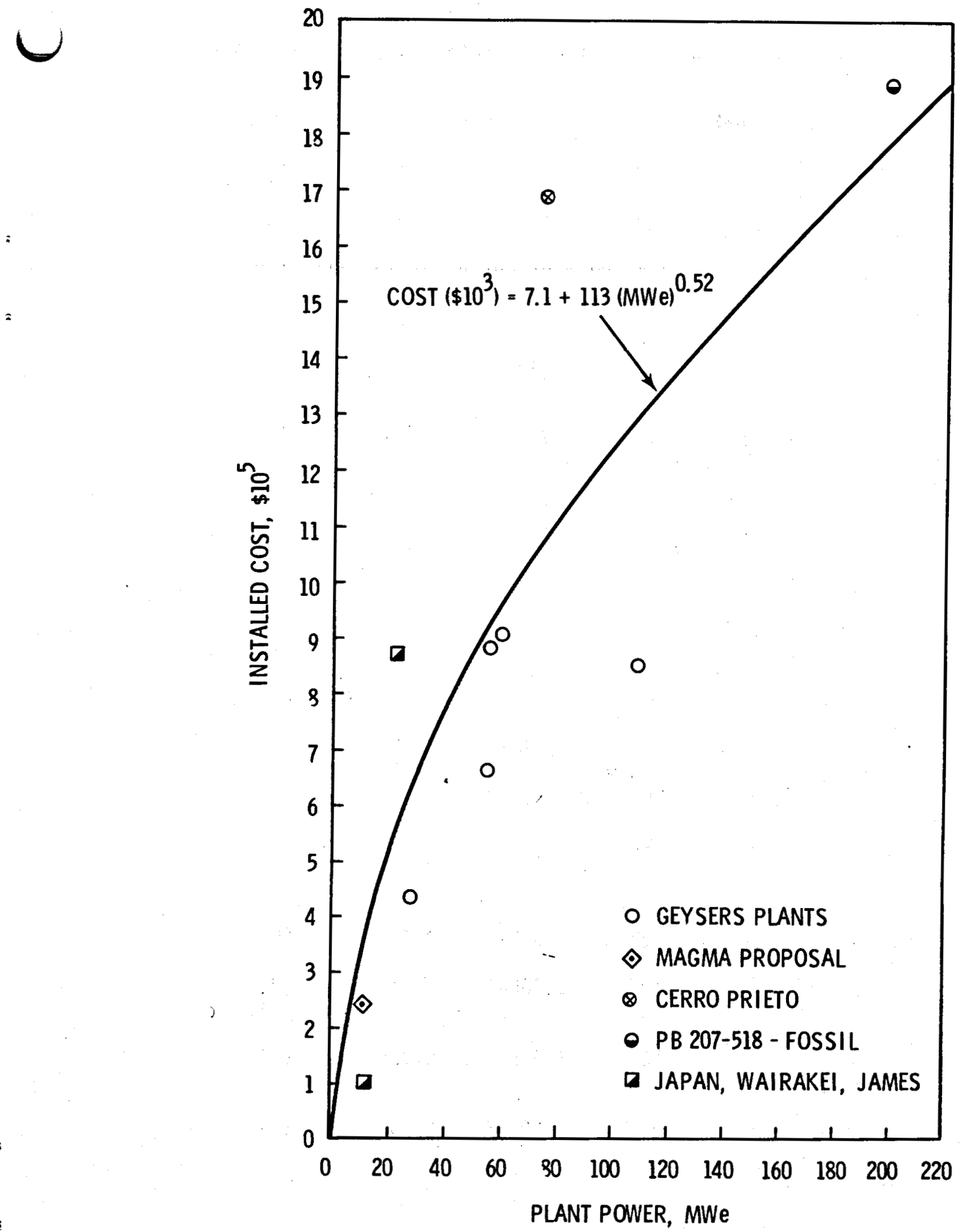

FIGURE 3.1-12. Switchyard - Installed Cost, $\$ 10^{5}$ Versus Plant Power, MWe 
TABLE 3-1. Flash Steam Power Plant Capital Cost Coefficients $\left(\$ 1975, \$ 10^{3}\right)$

\begin{tabular}{|c|c|c|c|c|c|}
\hline Account $\mathrm{N}$ & Component & a & b & $s$ & Comments \\
\hline & $\frac{\text { Power Plant }}{\text { Piping and Insulation }}$ & 767 & 224 & 1 & (1), (a) \\
\hline 1.1 .1 & $\begin{array}{l}\text { Piping and Insulation } \\
\text { Carbon Steel, Motor } \\
\text { Pumped System }\end{array}$ & 200 & $3.03 \mathrm{E}-4$ & 0.9 & (7) \\
\hline 1.1 .2 & $\begin{array}{l}\text { Piping and Insulation } \\
\text { Carbon Steel, Turbine } \\
\text { Pumped System }\end{array}$ & 242 & $6.96 \mathrm{E}-4$ & 0.869 & (7) \\
\hline 1.1 .3 & $\begin{array}{l}\text { Piping and Insulation } \\
\text { Stainless Steel, Motor } \\
\text { Pumped System }\end{array}$ & 500 & $3.54 \mathrm{E}-3$ & 0.80 & (7) \\
\hline 1.1 .4 & $\begin{array}{l}\text { Piping and Insulation } \\
\text { Stainless Steel, Turbine } \\
\text { Pumped System }\end{array}$ & $e^{576}$ & $1.65 \mathrm{E}-3$ & 0.869 & (7) \\
\hline $\begin{array}{l}1.2 \\
1.3\end{array}$ & $\begin{array}{l}\text { Crane } \\
\text { Turbogenerator }\end{array}$ & $\begin{array}{r}189 \\
42\end{array}$ & $\begin{array}{l}0.63 \\
5.9\end{array}$ & & $\begin{array}{l}\text { (1) } \\
\text { (1) }\end{array}$ \\
\hline 1.6 & $\begin{array}{l}\text { Flashers (Plant } \\
\text { Located Units) }\end{array}$ & +0 & 0.44 & 0.68 & $\begin{array}{l}(2) \\
(3)\end{array}$ \\
\hline $\begin{array}{l}1.9 \\
1.10\end{array}$ & $\begin{array}{l}\text { Misc. Support Equipment } \\
\text { Instrumentation and } \\
\text { Controllers }\end{array}$ & 0 & 5.2 & 0.85 & $\begin{array}{c}(1) \\
\text { See Table 3-2 }\end{array}$ \\
\hline 1.12 & $\begin{array}{l}\text { Electrical Support } \\
\text { Equipment }\end{array}$ & & & & See Table 3-3 \\
\hline $\begin{array}{l}1.16 \\
1.17 \\
1.18\end{array}$ & $\begin{array}{l}\text { Condenser } \\
\text { Installation Testing (b) } \\
\text { Buildings, Structures, } \\
\text { and Foundations }\end{array}$ & $\begin{array}{l}437 \\
5.9 \\
295\end{array}$ & $\begin{array}{l}7.2 \mathrm{E}-4 \\
3.5 \\
28\end{array}$ & $\begin{array}{l}1 \\
1 \\
1\end{array}$ & $\begin{array}{l}(2) \\
(1) \\
(1)\end{array}$ \\
\hline 1.19 & $\begin{array}{l}\text { Gas Ejectors (Steam } \\
\text { Driven) }\end{array}$ & 92 & 1.9 & 0.6 & (4) \\
\hline $\begin{array}{l}1.20 \\
1.20 .1 \\
1.20 .1 .1\end{array}$ & $\begin{array}{l}\text { Pumps } \\
\text { Cooling Water Pump } \\
\text { Cooling Water Pump, Motor } \\
\text { Driven, Carbon Steel }\end{array}$ & 27.1 & $1.56 \mathrm{E}-4$ & 0.761 & (8) \\
\hline 1.20 .1 .2 & $\begin{array}{l}\text { Cooling Water Pump, } \\
\text { Turbine Driven, } \\
\text { Carbon Steel }\end{array}$ & 107 & $2.26 \mathrm{E}-6$ & 1 & (8) \\
\hline 1.20 .1 .3 & $\begin{array}{l}\text { Cooling Water Pump, } \\
\text { Motor Driven, } \\
\text { Stainless Steel }\end{array}$ & 155 & 1. $68 \mathrm{E}-4$ & 0.826 & (8) \\
\hline 1.20 .1 .4 & $\begin{array}{l}\text { Cooling Water Pump, } \\
\text { Turbine Driven, } \\
\text { Stainless Steel }\end{array}$ & 250 & $1.92 E-5$ & 0.945 & (8) \\
\hline
\end{tabular}


Table 3-1. (continued)

Account No.

Component

a

b

$\mathbf{S}$

Comments

1.20.2 Flash Water Reinjection.

Pump (Plant Located

Flasher Unit)

1.20.3 Cooling Tower Blowdown Reinjection

1.99 Total 1.0

2.0 Heat Rejection System

$\begin{array}{lll}2.1 & \text { Wet Cooling Tower System } 800 & 7.0 \mathrm{E}-4 \\ 2.2 & \text { Dry. Cooling Tower System } 0 & 8730 \\ 2.99 & \text { Total } 2.0 & \end{array}$

$\begin{array}{llllll}3.0 & \text { Switchyard } & 7.1 & 113 & 0.52\end{array}$

3.99 Total 3.0

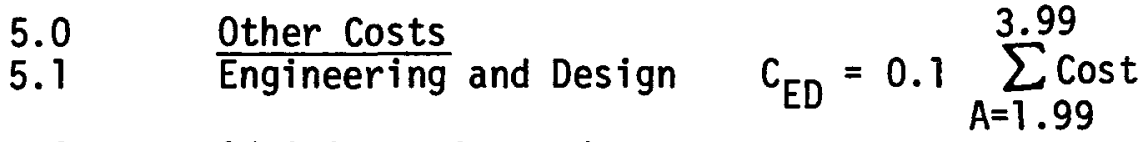

5.2 Administration and

5.99 Total 5.0

Indirect costs

$0.8 C_{E D}$

(1) Use $x=$ plant power (MWe)

(2) Use $x=$ total steam flow rate $(1 \mathrm{~b} / \mathrm{hr})$

(3) Cost of flashers $\left(\$ 10^{3}\right)=\sum_{N}(2)(5.2 E-4)$ (exit steam flow rate from each flash stage, $\mathrm{lb} / \mathrm{hr}$ ) - (water inlet pressure to each flash stage, Psi)

Exp 0.098 where $N=$ number of flash stages.

(4) Use $x=$ gas ejection rate (cfm)

(5) Same equations as account 1.20.1, use $x=$ flash reject water flow rate $\times$ pump head, $\frac{1 \mathrm{bm}}{\mathrm{hr}} \times \frac{\mathrm{lbf}}{\mathrm{in}^{2}}$

(6) Same equations as account 1.20.1, use $x=$ excess cooling water flow rate $\times$ pump head, $\frac{1 \mathrm{bm}}{\mathrm{hr}} \times \frac{\mathrm{lbf}}{\mathrm{in}^{2}}$

(7) Use $x=$ summed steam flow at flasher $(s), \mathrm{ft}^{3} / \mathrm{hr}$

(8) Use $x=$ total steam flow $x$ pump head, $\frac{1 \mathrm{bm}}{\mathrm{hr}} \times \frac{\mathrm{lbf}}{\mathrm{in}^{2}}$

(9) Use $x=10^{9}$ Btu/hr rejected from tower

(a) Estimate based on worldwide geothermal flash or dry steam plant costs.

(b) Optional 
TABLE 3-2. Cost Factors for Instrumentation and Controllers*

1.10 Instrumentation and Controllers

Pumps, Motor or Turbine

Pressure Vessels, Tanks, etc.

Buildings, Structures, and Foundations

Cooling Towers

Misc. Support Equipment

Heat Exchangers
Account No. \% of Capital Cost

1.20

5.5

1.6

10.9

1.18

5.8

2.0

1.2

1.9

13.1

1.16

17.8

TABLE 3-3. Cost Factors for Electrical Support Equipment*

1.12 Electrical Support Equipment

Pumps - Motor

Pumps - Turbine

Pressure Vessels, Tanks, etc.

Buildings, Structures, and Foundations

Cooling Towers

Misc. Support Equipment

Heat Exchangers
Account No. \% of Capital Cost

5.7

1.20

0.9

1.6

9.0

1.18

4.2

2.0

4.6

1.9

14.9

1.16

3.6

* I\&C and electrical support equipment costs are already included in components not specified in above lists. 


\subsection{BINARY PLANT}

The binary plant uses the geothermal fluid to heat and vaporize a secondary working fluid in the power generation circuit. A few of the plant components are cormon to both binary and flash steam plants; however, most components are specific to the binary cycle. It was assumed, for the purposes of this study, that the binary plant application used a non-water secondary working fluid and thus requires the special plant components for non-steam power generation cycles. For higher temperature geothermal sources, water can be used as a secondary cycle working fluid. This option is available for analysis as a special case for the hybrid plant described in Section 5.0.

\subsection{Binary Power Plant Costs}

The costs for the binary plant sere developed in part from a study conducted by Vitor Corp. ${ }^{(4-1)}$ as a subcontract to the BNW Geothermal Economics Program. This study was undertaken to clarify differences in component cost estimates among the various A-E studies, and obtain additional data as discussed in footnote (a), page 2. Flash steam plant data are also used where appropriate to the binary plant (see Table 4-1). Two additional sources are used, studies by Jonsson ${ }^{(4-2)}$ and Magma. ${ }^{(4-3)}$ This represents a fairly limited base for the specific binary equipment $(4-1,2,3)$ but an adequate base for the steam equipment which can be used in the binary plant cost formulations. (3-1 to -21). Other data sources were not available due to the specialized nature of the binary plant equipment and the lack of generalized treatment in the geothermal literature. Comparisons of binary GEOCOST estimates with those of A-E's show good correspondence; these are discussed in Section 5 of this report.

\subsubsection{Piping, Insulation, and Tanks}

The Vitro study ${ }^{(4-1)}$ provides a thorough assessment of costs for carbon and stainless steel systems using motor or turbine driven pumps. It is expected that carbon steel will be the material of construction due to the non-corrosive nature of the more prominent binary working fluids. Vapor volume flow provided the best correlation since vapor piping tends to 
dominate the pipe cost account. Piping schedules do not change for the selected working fluid (isobutane) within the range of temperatures examined $\left(270^{\circ} \mathrm{F} / 344\right.$ psia to $\left.540^{\circ} \mathrm{F} / 794 \mathrm{psia}\right)$. Figure $4.1-1$ presents the data and equations graphically. The equations are also listed in Table 4-1.

\subsubsection{Plant Crane}

The correlation used for this component is the flash steam plant equation. The lower limit capacity for the crane is $30,000 \mathrm{lb}$ based on a $5000 \mathrm{ft}^{2}$ heat exchanger module. Otherwise, the generator weight dictates the crane size.

\subsubsection{Turbogenerator}

The turobgenerator cost correlation is shown in Figure 4.1-2. Some of the data were obtained from References 4-2 and -3 which represents a fairly limited data base, consequently data from the three A-E estimates for binary turbogenerators is also used. $(4-8,-9,-10)$ Vendor data were not available for this binary plant component.

\subsubsection{Vapor Generator, Auxiliary Heat Exchangers; Desuperheater, and Condenser}

The correlations for the binary plant heat exchangers were developed from studies conducted at BNW ${ }^{(4-4)}$ and LASL, ${ }^{(4-5)}$ which used vendor data extensively. Heat exchangers were costed in $5000 \mathrm{ft}^{2}$ modules with shell and tube thicknesses dependent upon internal pressures. The resultant formulation for heat exchanger costs is shown in Tables 4-1 and 4-4.

\subsubsection{Miscellaneous Support Equipment}

Data specific to binary plants were not available for this category of equipment. Consequently, the flash plant equation is being used. (See Table 4-1 and Figure 3.1-4.

\subsubsection{Instrumentation and Controllers}

The Vitro study ${ }^{(4-1)}$ provides a detailed apportionment among the various plant equipment for instrumentation and controllers as percentages of the equipment costs. A more detailed discussion of I\&C costs is presented in Section 3.1.5. The percentage costs for I\&C are 1isted in Tables 4-1 and 4-2. 


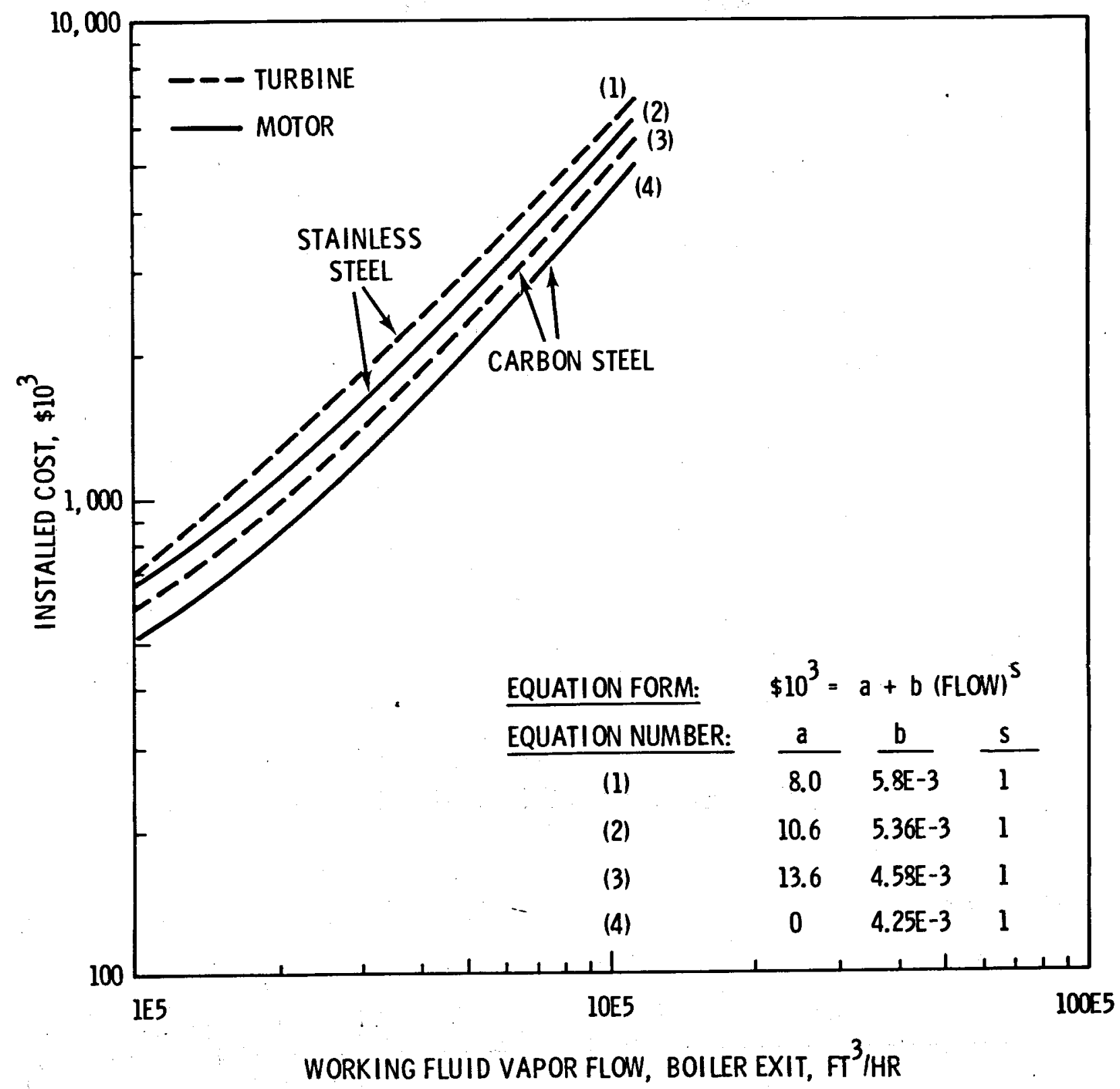

FIGURE 4:1-1. Binary Plant Installed Cost--Piping, Insulation, and Tanks for Carbon and Stainless Steel Systems, Using Motor Driven or Turbine Driven Pumps-Installed Cost Versus Boiler Exit Volume Flow 


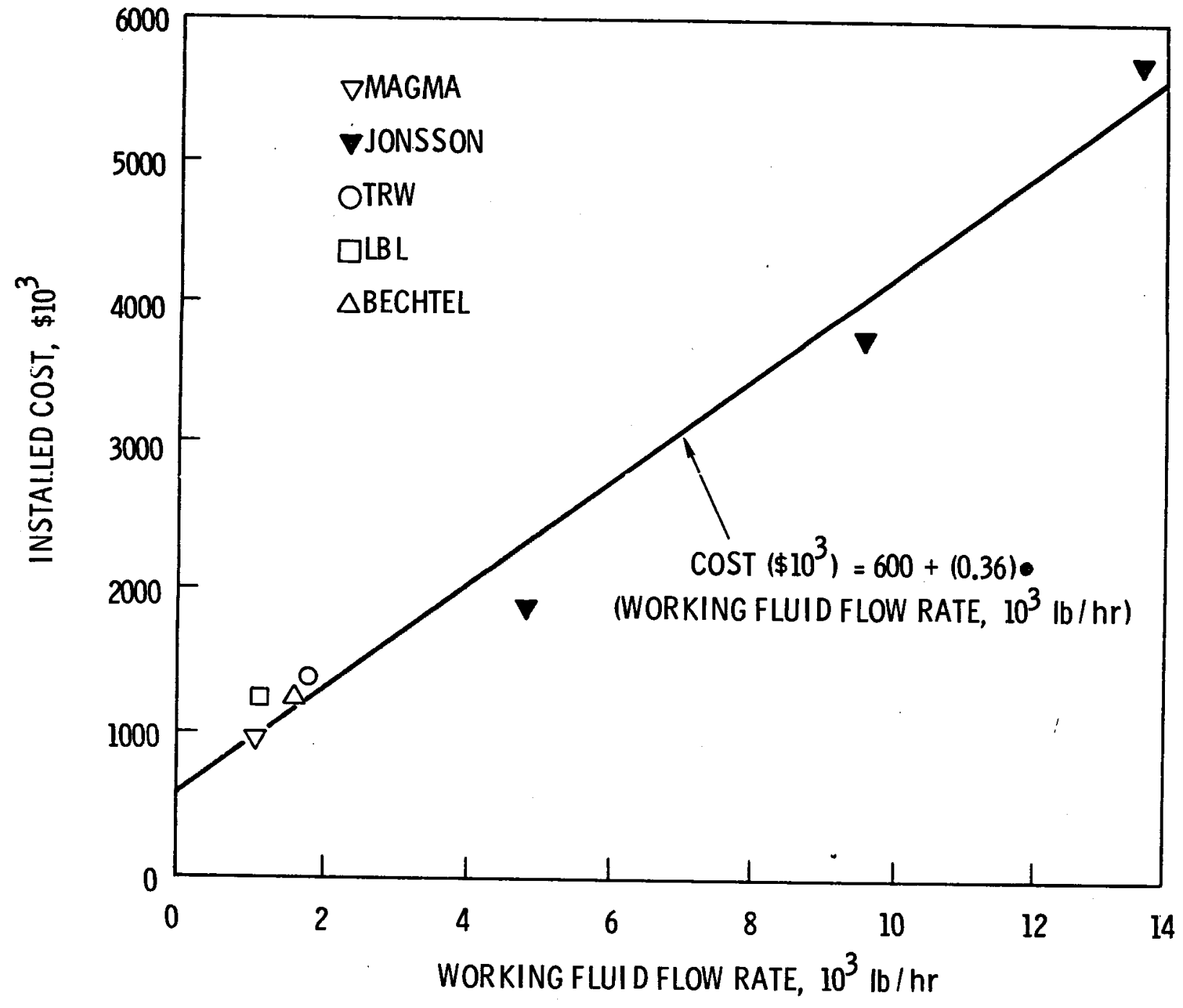

FIGURE 4.7-2. Binary Plant Turbogenerator - Installed Cost, $\$ 10^{3}$ Versus Working Fluid Flow Rate, $10^{3} \mathrm{lb} / \mathrm{hr}$ 


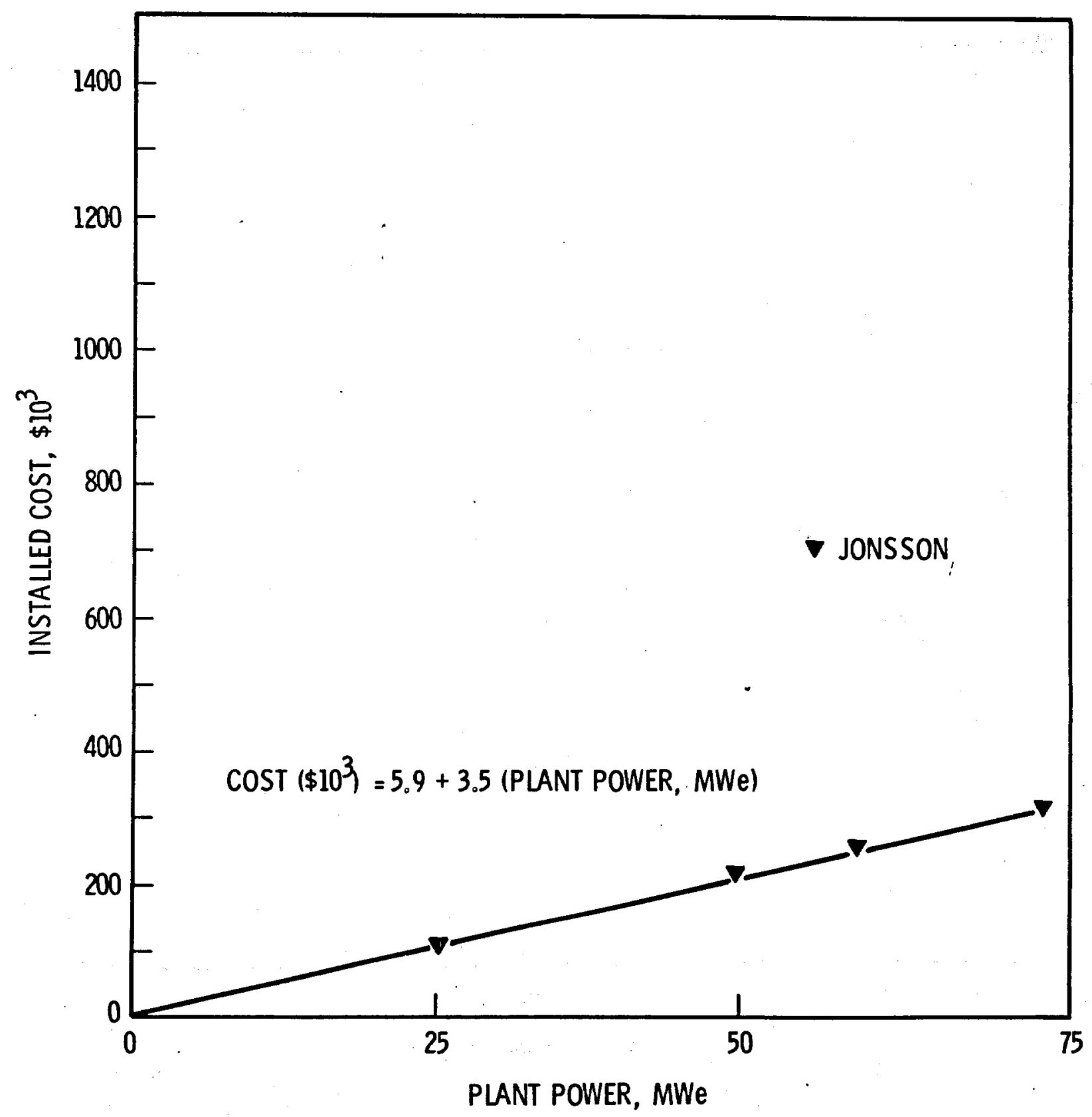

FIGURE 4.1-3. Binary Plant Installation Testing Cost, Versus Plant Power, MWe 


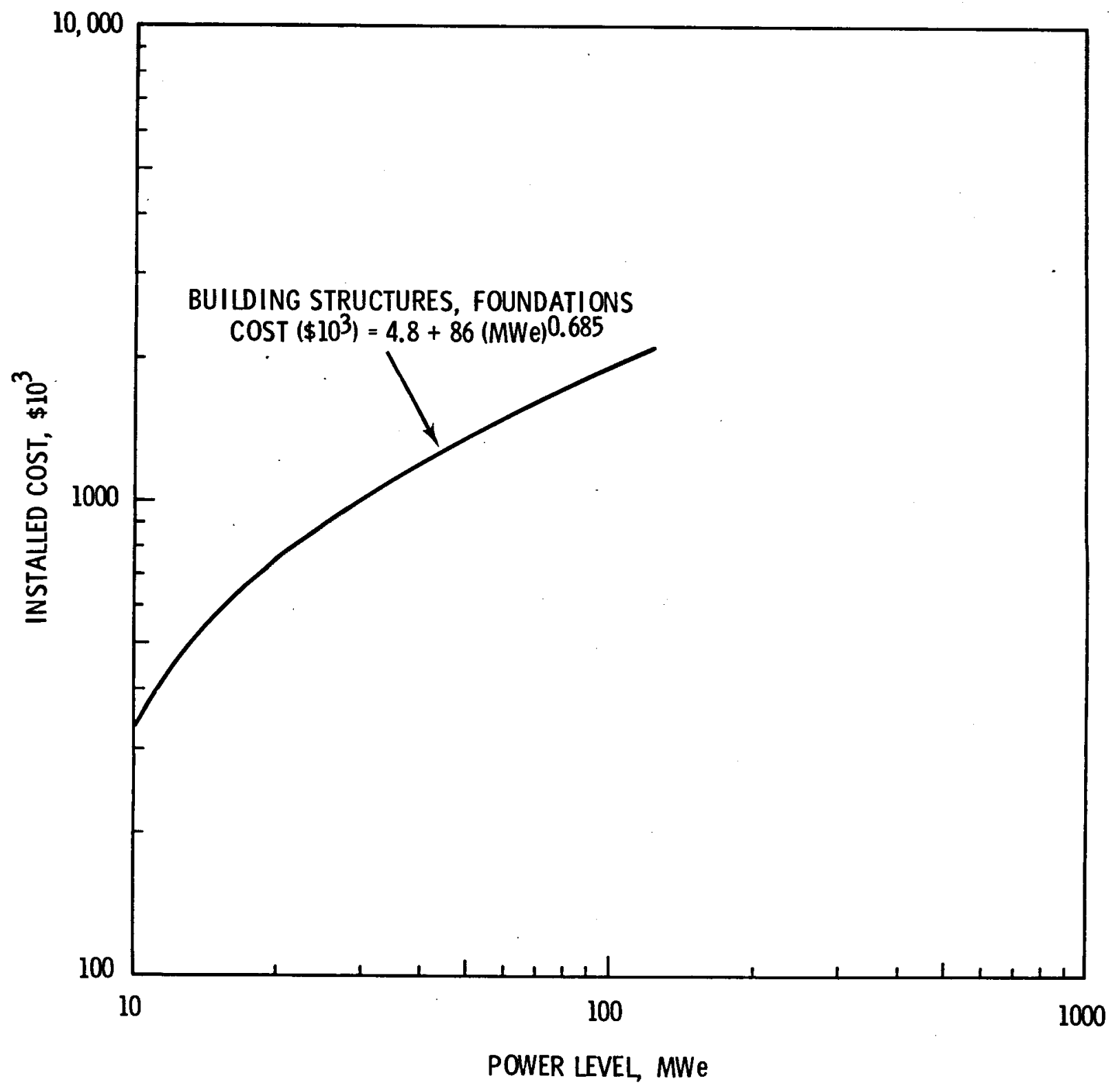

FIGURE 4.1-4. Installed Cost for Binary Plant Buildings, Structures, and Foundations 


\subsubsection{Electrical Support Equipment}

The Vitro study $(4-1)$ provides the same type of apportionment described in 4.1.6. The percentage values are listed in Tables 4-1 and 4-3. Section 3.1.6 presents a more complete discussion for electrical support equipment for both motor and turbine pumped systems.

\subsubsection{Installation Testing}

Data for this item, also discussed in Section 3.1.8, is obtained from Reference 4-2. It represents a capital expense because it is a service performed by the contractor prior to utility takeover. Table 4-1 lists the correlation for the binary plant; It is treated as an optional item in the cost summary. Figure 4.1-3 provides the data graphically.

\subsubsection{Buildings, Structures, and Foundations}

The Vitro study ${ }^{(4-1)}$ examined the requirements for buildings, structures, and foundations for three size plants, 10, 50, and 100 MWe. The results of this study are shown in Figure 4.1-4. Actual costs in this category can be expected to vary considerably due to site dependent characteristics. Table 4-1 lists the correlation for this account.

\subsubsection{Binary Fluid Pumps}

Vitro ${ }^{(4-1)}$ examined the installed costs for binary fluid pumps within the plant complex. These include the booster and boiler feed pumps. Both motor and turbine-driven pumps were costed. Carbon steel was specified as the pump material due to the noncorrosive nature of the working fluids examined. Figure 4.1-5 presents the data; the correlation equations are Tisted in Table 4-1.

\subsubsection{Reinjection Pumps (Geothermal Fluid)}

These water service pumps were costed in the Vitro study ${ }^{(4-1)}$ and are discussed in Section 3.1.12. Motor- and turbine-driven pumps are examined for both stainless and carbon steel construction.

\subsubsection{Cooling Towers}

Both wet and dry cooling tower costs are modeled in this account. Wet cooling towers could not be modeled on a condensate flow or Tower Unit basis 


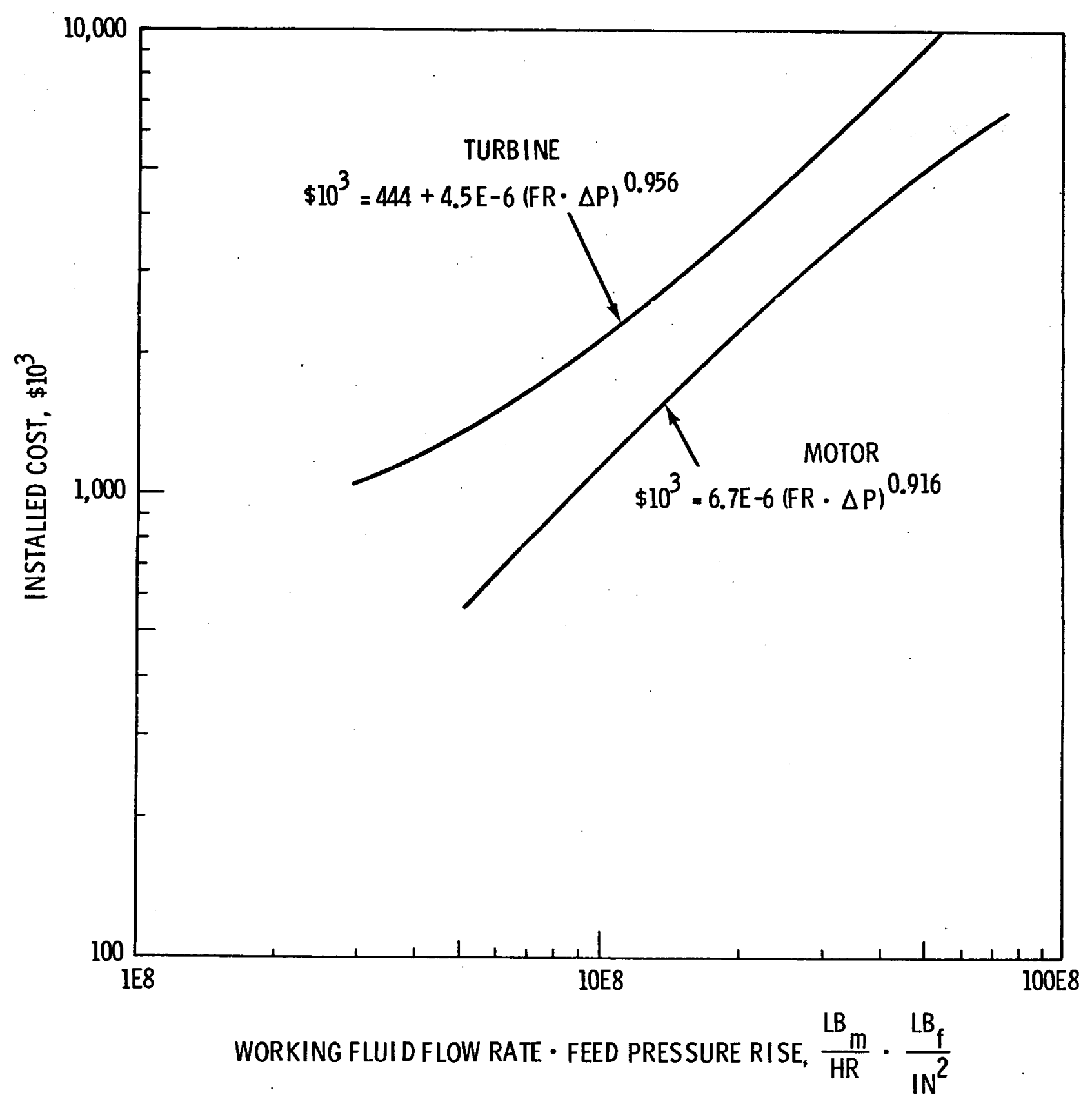

FIGURE 4:1-5. Binary Plant Installed Pump Costs, Carbon Steel 
because of uncertainties in the binary working fluid tower performance characteristics. Instead, it was decided to model both cooling systems on the basis of $Q_{\text {reject. Marley }}{ }^{(4-7)}$ points out that the capital cost error in this method is $\pm 24 \%$. However, this error appears to be within the limits expected for estimates on a binary cooling tower. The cost equations are shown in Table 4-1. 
TABLE 4-1. Binary Power Plant Capital Cost Coefficients $\left(\$ 1975, \$ 10^{3}\right)$

\begin{tabular}{|c|c|c|c|c|c|}
\hline Account & Component & a & b & s & Comments \\
\hline 1.0 & Power Plant & & & & \\
\hline 1.1 & Piping, Insulation, and Tanks & & & & \\
\hline 1.1 .1 & $\begin{array}{l}\text { Piping, Insulation, and } \\
\text { Tanks - Carbon Steel, } \\
\text { Motor Pumped System }\end{array}$ & 0 & $4.25 \mathrm{E}-3$ & 1 & (8) \\
\hline 1.1 .2 & $\begin{array}{l}\text { Piping, Insulation, and } \\
\text { Tanks - Carbon Steel, } \\
\text { Turbine Pumped System }\end{array}$ & 136 & $4.58 \mathrm{E}-3$ & 1 & (8) \\
\hline 1.1 .3 & $\begin{array}{l}\text { Piping, Insulation, and } \\
\text { Tanks - Stainless Steel, } \\
\text { Motor Pumped System }\end{array}$ & 10.6 & $5.36 \mathrm{E}-3$ & 1 & (8) \\
\hline 1.1 .4 & $\begin{array}{l}\text { Piping, Insulation, and } \\
\text { Tanks - Stainless Steel, } \\
\text { Turbine Pumped System }\end{array}$ & 8 & $5.8 E-3$ & 1 & (8) \\
\hline 1.2 & Crane & 189 & 0.63 & 1 & (1) \\
\hline 1.3 & Turbogenerator & 600 & 0.36 & 1 & (2) \\
\hline 1.5 & $\begin{array}{l}\text { Vapor Generator and } \\
\text { Auxiliary Heat Exchangers }\end{array}$ & & & & $(5)$ \\
\hline 1.9 & Miscellaneous Support Equip. & 0 & 5.2 & 0.85 & (1) \\
\hline 1.10 & Instrumentation and Controllers & & & & (6) \\
\hline 1.12 & Electrical Support Equipment & & & & (7) \\
\hline 1.16 & Condenser and Desuperheater & & & & (5) \\
\hline 1.17 & Installation Testing & 5.9 & 3.5 & 1 & (1) \\
\hline 1.18 & $\begin{array}{l}\text { Buildings, Structures, } \\
\text { and Foundations }\end{array}$ & 4.8 & 86 & 0.685 & (1) \\
\hline 1.20 & Binary Fluid Pumps & & & & \\
\hline 1.20 .1 & Pumps, Motor Driven & 0 & $6.7 E-6$ & 0.916 & (9) \\
\hline 1.20 .2 & Pumps, Turbine Driven & 444 & $4.5 \mathrm{E}-6$ & 0.956 & (9) \\
\hline 1.20 .3 & $\begin{array}{l}\text { Reinjection Pump } \\
\text { (Plant Located) }\end{array}$ & & & & (3) \\
\hline 1.99 & Total 1.0 & & & & \\
\hline
\end{tabular}


Table 4-1. (continued)

\begin{tabular}{|c|c|c|c|c|c|}
\hline Account & Component & $a$ & b & s & Comments \\
\hline 2.0 & Heat Rejection System & & & & \\
\hline 2.1 & Wet Cooling Tower System & 720 & 13 & 1 & (4) \\
\hline 2.2 & Dry Cooling Tower System & 0 & 8730 & 1 & (4) \\
\hline 2.99 & Total 2.0 & & & & \\
\hline 3.0 & Switchyard & 7.1 & 113 & 0.52 & (1) \\
\hline 3.99 & Total 3.0 & & & & \\
\hline 5.0 & Other Costs & \multirow{2}{*}{\multicolumn{4}{|c|}{$\sum_{A=1.99}^{3.99} \cos t$}} \\
\hline 5.1 & Engineering and Design & & & & \\
\hline 5.2 & $\begin{array}{l}\text { Administration and } \\
\text { Indirect Costs }\end{array}$ & 0.8 & $C_{E D}$. & & \\
\hline & Total 5.0 & & & & \\
\hline
\end{tabular}

(1) Use $x=$ plant power (MWe)

(2) Use $x=$ working fluid flow rate $\left(10^{3} \mathrm{lb} / \mathrm{hr}\right)$

(3) Use $x=[($ reinjection flow, lb/hr) (pressure increase, Psi)], and 1.20 .1 or 1.20 .2 equations.

(4) Use tower heat rejected, Q, $10^{9} \mathrm{Btu} / \mathrm{hr}$

(5) See heat exchanger cost equations, Table 4-4

(6) See I\&C data, Table 4-2

(7) See electrical support data, Table 4-3

(8) Use $x=$ working fluid vapor flow, boiler exit, $\mathrm{ft}^{3} / \mathrm{hr}$

(9) Use $x=$ [(working fluid flow rate, $\mathrm{lb} / \mathrm{hr}$ ) (feed pressure rise, psi)]

a Optional 
TABLE 4-2. Cost Factors for Instrumentation and Controllers*

1.10 Instrumentation and Controllers Account \% of Capital Cost

$\begin{array}{llr}\text { Pumps, Motor or Turbine } & 1.20 & 5.5 \\ \begin{array}{l}\text { Buildings, Structures, and } \\ \text { Foundations }\end{array} & 1.18 & 5.8 \\ \text { Cooling Towers } & 2.0 & 1.2 \\ \text { Miscellaneous Support Equipment } & 1.9 & 13.1 \\ \text { Heat Exchangers } & 1.5,1.16 & 17.8\end{array}$

TABLE 4-3. Cost Factors for Electrical Support Equipment*

1.12 Electrical Support Equipment

Account $\%$ of Capital Cost

$\begin{array}{llr}\text { Pumps - Motor } & 1.20 & 5.7 \\ \text { Pumps - Turbine } & 1.20 & 0.9 \\ \begin{array}{l}\text { Buildings, Structures, and } \\ \quad \text { Foundations }\end{array} & 1.18 & 4.2 \\ \text { Cooling Towers } & 2.0 & 4.6 \\ \text { Miscellaneous Support Equipment } & 1.9 & 14.9 \\ \text { Heat Exchangers } & 1.5,1.16 & 3.6\end{array}$

* IC and electrical support equipment costs already included in components not specified in above lists. 


\section{TABLE 4-4. Heat Exchanger cost Equations}

These equations are applicable to all plant heat exchangers.

1) $\operatorname{Cost}{ }^{(4-4)}\left(\$ 10^{3}\right)=93.3 E-3(H T A)^{0.78}$, for $P_{s} \leq 100$ Psia and $P_{t} \leq 200$ Psia. HTA = Heat Transfer Area, $P_{s}=$ Shell side pressure, $P_{t}=$ Tube side pressure

2) For $100<P_{s}<4000 P s i a$ and $200<P_{t}<1000 P s i a$

Use the following:

Modify the cost determined above by

Cost $=\frac{C_{1}}{12}(F)$

Where $F$ is a factor which accounts for tube and shell side pressures.

$F=F_{200}\left(\frac{F_{1000}}{F_{200}}\right)^{X}$

$x=\frac{P_{t}-200}{800}$

$\left.\begin{array}{l}F_{200}=2.6+1.25\left(P_{s}\right) 0.44 \\ F_{1000}=12.1+0.40\left(P_{s}\right) 0.60\end{array}\right\}$ 


\subsection{CAPITAL COST COMPARISONS}

Analyses were performed to compare the capital costs between GEOCOST and A-E estimates for the following power plants:

1. Aeroject Nuclear, 15 MWe, 2 Flash Steam Plant, $300^{\circ} \mathrm{F}$ Brine, Flash $1,206^{\circ} \mathrm{F}$ Flash $2 .^{(5-1)}$

2. LBL, 10 MWe, Binary Isobutane Plant, $392^{\circ} \mathrm{F}$ Brine ${ }^{(5-2)}$

3. TRW, 10 MWe, Binary Isobutane Plant, $350^{\circ} \mathrm{F}$ Brine $e^{(5-3)}$

4. Bechtel, $10 \mathrm{MWe}$, Binary Isobutane Plant, $380^{\circ} \mathrm{F}$ Brine ${ }^{(5-5)}$

The four-plant cost estimates cited above were developed in 1974. The estimated dollar cost of the plant components were escalated by 1.18 to put them in terms of EOY 1975\$ (see Table 1-1). Differences between 1) the plant designs and equipment apportionment categories, and 2) GEOCOST required: 1) adjustment in GEOCOST operating conditions to simulate the A-E cycles, and 2) sorting among the equipment categories to provide a closer simulation of both the A-E operating conditions and cost estimates.

The references cited for each plant contain cost estimates prepared by Rogers Engineering, nos. 1, 2, 3, and Bechtel no. 4. The GEOCOST estimates and the Rogers estimates are compared in Table $5-1,-2,-4,-5$, and -6. A number of differences show up for individual total, and component cost estimates between GEOCOST and the A-E's. These differences can be expected for the several reasons as cited below.

1. Differences between plant design assumptions by the A-E and GEOCOST

2. GEOCOST represents, in most cases, industry averages versus single contractor estimates for a first-of-a-kind plant

3. Differences between A-E and GEOCOST methods of apportioning component and supporting equipment costs, and

4. The usual variations experienced in cost estimating. 
These comparisons show that 1) the steam plant cost estimates by GEOCOST are consistent from both total plant cost and specific component cost standpoints, and 2) binary plant GEOCOST total estimates generally agree with Rogers. The Bechtel estimates runs about $60 \%$ above GEOCOST. However, differences in plant design* between GEOCOST and the A-E's lead to large variations in some specific equipment costs. Further, the apportionment of equipment costs among various categories in GEOCOST versus the A-E's varies considerably. The apportionment in the Rogers estimates are consistent, but vary from both GEOCOST and Bechtel. Similarly, the Bechtel apportionment differs from GEOCOST.

Section 5.1.5 presents a comparison of TRW, GEOCOST, Rogers/TRW, and Bechtel cost estimates for geothermal binary plants. $(5-1,-2,-3,-5)$ These plants range in size from 3 to 50 MWe. GEOCOST estimates fall in the high mid-range of the data, with the TRW data on the low side and the Bechtel data on the high side. The Rogers/TRW and LBL/Rogers data appear to match GEOCOST closely. The GEOCOST estimates fall in the median area of industry estimates. It should be noted that the wide range of cost estimates suggests a limited level of confidence for these plant cost projections.

A comparison was made for Geysers data reported by PG\&E at the U.N. Geothermal Symposium at San Francisco in May 1975. (5-7) PG\&E data reported for Geysers plants $(\$ 16,350 \mathrm{~K}$ for 110 MWe and $\$ 11,383 \mathrm{~K}$ for 55 MWe) were 1973 California Public Utility submittals and not updated for full 1975 cost escalation. Full escalation for 1975 brings these plant costs up to $\$ 192 / \mathrm{kW}$ for the $110 \mathrm{MW}$ plant and $\$ 280 / \mathrm{kW}$ for the $55 \mathrm{MW}$ plant. The same basis GEOCOST estimates for these plants are $\$ 232 / \mathrm{kW}$ and $\$ 275 / \mathrm{kW}$ respectively.

The details of the individual binary plant and component cost estimates are discussed in the following sections.

* Specifically, for these designs, the application of regenerators from the turbine pump exhausts. 


\subsection{Detailed Evaluation}

This section evaluates the results of the cost comparison studies. Differences between the cost estimates are discussed and resolved where possible. If the cost estimate differences between GEOCOST and Rogers are within the expected variation of these estimates, the results are judged comparable and not discussed. The Bechtel estimate is treated separately due to its wide variance from both GEOCOST and the other A-E estimates.

\subsubsection{Aerojet Nuclear, 15 MWe, 2 Flash Plant $\left(300^{\circ} \mathrm{F}\right.$ Brine; Flash $1250^{\circ} \mathrm{F}$; Flash 2, 206 $\mathrm{F}$ )}

The cost estimates shown in Table 5-1 compare quite favorably; GEOCOST $(\$ 10,503,000)$ versus Rogers $(\$ 9,663,000) 1975 \$$ 's. The flash steam plant total cost estimates computed by GEOCOST agree within 10\% as shown here and with the Geysers plants discussed above. The following analyzes the individual component cost estimate differences.

Account 1.1, Piping and Insulation: A large cost difference shows up in this plant item, $\$ 730 \mathrm{~K}$ GEOCOST versus $\$ 159 \mathrm{~K}$ kogers. The Rogers estimate appears to apportion some of the piping costs in the Buildings Account 1.18, and perhaps in the field (steam) transmission and disposa1 systems.

Account 1.2, Crane: Rogers states that Crane costs (unspecified) are included in Account 1.18, Buildings, Foundation, and Support Equipment.

Account 1.3, Turbogenerator: GEOCOST includes electrical support equipment for the turbogenerator in the 1.3 Account, thus the higher GEOCOST estimate. Rogers includes the turbogenerator support equipment in Account 1.12, Electrical Support Equipment. GEOCOST includes al1 turbogenerator equipment in the turbogenerator account.

Account 1.12, Electrical Support Equipment: Rogers estimate is several times higher than GEOCOST. The major reason is Rogers' inclusion of cooling tower fans, turbogenerator electrical support equipment, and switchyard costs in this Electrical Support Equipment (1.12) category. Summing Accounts 1.3, 1.12, 2.0, and 3.0 shows GEOCOST at $\$ 5,032,000$ and Rogers at $\$ 4,357,000$, a difference of on $1 y 15 \%$. 
TABLE 5-1. Comparison of Idaho Falls and GEOCOST Flash Plant Capital Costs

10 MWe Net

15 MWe Gross

POWER PLANT CAPITAL COSTS

Account

1.0 Power Plant

1.1 Piping and Insulation

1.2 Crane

1.3 Turbogenerator

1.6 Flashers (Plant Located Units)

1.9 Misc. Process Support Equipment

1.10 Instrumentation and Controllers

1.12 Electrical Support Equipment

1.16 Condenser

$\omega$

1.17 Installation Testing

1.18 Buildings, Foundations, and Support Equipment

2.0 Heat Rejection System (Cooling Towers)

2.1 Cooling Tower System (Forced Draft Wet)

3.0 Switchyard

3.99 Subtotal 3.0

Total 1.0, 2.0, 3.0

5.0 Other Costs

5.1 Engineering and Design, PNL (10\%)

5.2 Administration and Indirect costs, PNL (8\%)

5.99 Subtotal 5.0

Total Power Plant Cost
GEOCOST

\$K

730

198

3264

363

52

263

174

786

59

720

298

400

7307

1124

2 Plt. Flash

Rogers Engr.

Estimate

159

Incl. in 1.18

2394

248

Incl. throughout

209

1382, Incl. Cooling Tower

743

Not shown

1647

558 Uses Pumps

120 Incl. in 1.16

7340

581 Elec. incl. in 1.12

$\frac{470}{8901}$

Incl. in 1.12

7921

$\begin{array}{r}890 \\ 712 \\ 7602 \\ \hline\end{array}$

$7 \%=$

$15 \%=$

554

1188

1742

10503 
Account 1.18, Buildings, Foundations, and Support Equipment: Rogers costs run more than twice GEOCOST. There are several reasons for this: Rogers includes the crane where GEOCOST provides a separate account for that item. Rogers also lumps most nonelectrical support equipment in this account; again, GEOCOST provides a separate account for this item. GEOCOST uses the Geysers and other dry steam plants for the Account 1.18 estimates. Also, Rogers building costs may be heavily site dependent, and appear to contain portions of the plant piping costs.

Account 1.19, Gas Ejectors: GEOCOST estimates steam driven ejectors whereas the Rogers estimate uses the more expensive vapor compression pumps. The pumped system may be more expensive from a capital cost standpoint but perhaps not from an operating cost standpoint: operating costs also depend upon geothermal steam charges.

Account 1.20, Pumps: Rogers includes pump costs in the condenser system, Account 1.16, whereas GEOCOST shows a separate item, $\$ 400 \mathrm{~K}$, for pumps. The sum of the two accounts, 1.20 and 1.16, differ significantly, $\$ 1186 \mathrm{~K}$ GEOCOST versus $\$ 743 \mathrm{~K}$ Rogers. Pumps appear to be the major factor causing the difference. Since both estimates are made on the basis of vendor quotations, (Vitro provided the GEOCOST estimates), ${ }^{(5-7)}$ the explanation of these differences will require further study. Some of the Rogers pump costs may be included in the field and disposal accounts.

Accounts 2.0 and 3.0, Cooling Towers and Switchyard: See comment for Account 1.12. The GEOCOST estimates are believed accurate based upon Geysers, Cerro Prieto, Matsukawa, and Wairakei data.

Account 5.0, Other costs: The 18\% estimate in GEOCOST is based on a United States average. ${ }^{(5-4)}$ The $22 \%$ used by Rogers is higher than this U.S. average, but probably appropriate for their first-of-akind plant. 


\subsubsection{LBL, 10 MWe, Binary Isobutane Plant ( $392^{\circ} \mathrm{F}$ Brine)}

The two cost estimates, Table 5-2, agree within about 5\%. Total

power plant cost by GEOCOST $=\$ 9,583,000$ versus Rogers estimate $=\$ 9,896,000$. However, the individual component estimates in Table 5-2 does not show the same high level of agreement obtained in the flash steam model. A major difference between the GEOCOST binary cycle and the cycle proposed by LBL is the use of turbine pumps for boiler feed, rather than the electrically driven pumps in the GEOCOST cycle model. However, turbine pumps are costed for GEOCOST in Table 5-2, but based on plant flows for an electrically pumped system. Another difference is the use of economizers to extract heat from the main and pump turbine exhausts. GEOCOST does not currently model economizers.* These cycle differences lead to the rather large individual component cost estimate variations.

Account 1.2, Crane: Rogers has included the estimate for this item in the account corresponding to 1.9, Miscellaneous Process Support Equipment.

Account 1.3, Turbogenerator: Major differences in turbogenerator costs cannot be easily reconciled. The cost of a comparable steam turbogenerator is about $\$ 2,600,000$. GEOCOST binary turbogenerator costs should have been higher than Rugers since the total working fluid passes through the main turbine in GEOCOST versus the bypass for the turbine pumps in the Rogers design. Also GEOCOST includes associated electrical equipment for the turbogenerator in Account 1.3, whereas Rogers includes it in their account corresponding to Account 1.12, Electrical Support Equipment. Thus, one would expect the GEOCOST turbogenerator cost to be still higher.

Account 1.5, Vapor Generator and 1.7, Auxiliary Heat Exchangers:

Rogers estimates are much higher than GEOCOST because of the extensive use of economizers by Rogers to extract heat from the main and pump turbine exhausts.

‡ Discussions with TRW indicate that economizers provided a more optimum plant for TRW than one which operates at lower turbine exhaust without economizers. The high capital cost for the equipment was justified by the improved overall operating cost. This is apparently also the case in the LBL plant. 
TABLE 5-2. Comparison of LBL Binary and GEOCOST Plant Capital cost

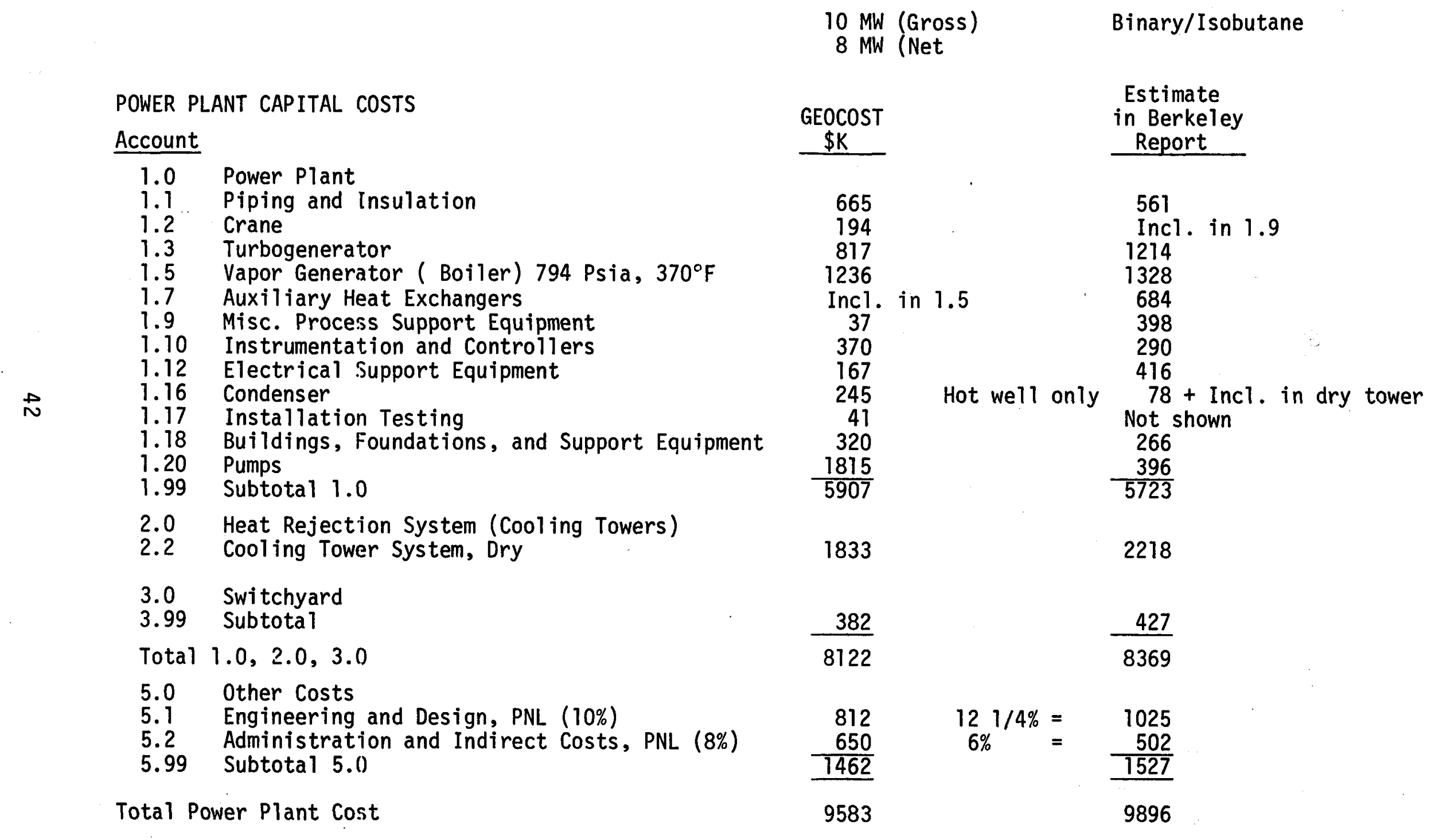


Account 1.9, Miscellaneous Process Support Equipment: The large difference in this item is due in part to the assignment of Rogers "5\% Sma11 Miscellaneous Equipment," charges to this account, although more auxiliary equipment is needed for the cycle selected by Berkeley versus the GEOCOST cycle. Rogers may also lump service support equipment in this account rather than in GEOCOST 1.18.

Account 1.10, Instrumentation and Controllers: GEOCOST estimates are made for a "production" type plant rather than the highly instrumented first-of-a-kind plant as Rogers and LBL have designed.

Account 1.12, Electrical Support Equipment: Rogers costs are about twice the GEOCOST estimate. This may be due to Rogers assignment of cooling tower electrical equipment to Account 1.12 rather than the tower Account 2.1. Also, Rogers first-of-a-kind factors may be working here.

Account 1.16, Condenser: Rogers estimates include the condenser costs in the colling tower, Account 2.2, except for the hot well. Account 1.18, Buildings, Foundations, and Support Equipment: These costs are higher in GEOCOST as compared to Rogers. GEOCOST estimates are based on the Vitro study. ${ }^{(5-7)}$ The site dependent characteristics of this cost estimate may account for the cost differences. The GEOCOST 1.18 estimate also includes service support equipment which may be included in Rogers 1.9 account.

Account 1.20, Pumps: The cost estimates for pumps differ significantly; $\$ 1815 \mathrm{~K}$ by GEOCOST vs. $\$ 396 \mathrm{~K}$ by Rogers. The estimates for these turbopumps are both based on vendor quotations. Resolution of the differences cannot be provided at this time. See comments for Account 1.20, Section 5.1.2.

Account 2.2, Dry Cooling Tower: The dry cooling tower Account predicts similar costs in GEOCOST versus Rogers estimate. Both the TRW and Berkeley plants use dry cooling towers. Dry towers represent a significant portion of the plant costs; Table 5-3 compares GEOCOST and Rogers estimates in $\$$ and \% of total plant cost versus wet towers. 
Dry towers show a much higher cost when compared to wet towers for geothermal plants. This cost increase shows up in both capital charges and operating expenses (lowered efficiency). In many locations, however, the cooling option may be restricted to dry towers. Table 5-3 provides a comparison of dry and wet tower capital costs.

TABLE 5-3. Cost Comparison for Wet and Dry Cooling Towers

Plant

\section{TRW}

Berkeley

$\frac{\text { GEOCOST Wet Tower }}{\$ 10^{6}} \begin{gathered}\text { Percent of } \\ \text { Total Plant Cost }\end{gathered}$

ح0.25
2.3

2.0

$\frac{\text { Rogers Dry Tower }}{\$ 10^{6} \quad \begin{array}{c}\text { Percent of } \\ \text { Total Plant Cost }\end{array}}$

2.59

1.83
23

18

The use of dry towers is a major economic penalty for the binary system, both from the standpoints of plant efficiency and tower cost. GEOCOST estimates the tower capital cost, but does not model dry towers in the power cycle at this time. Thus, the added capital and operating expense due to the higher working fluid flows, and lower efficiency, is not present in the GEOCOST estimates. Table 5-3 shows that the capital expense of dry towers is a significant percentage of the total plant cost. Wet towers, for example, run about $1 / 10$ of the dry tower costs estimated here. The efficiency loss associated with dry towers is also an important cost penalty. Geothermal plants generally run at a lower efficiency than fossil fired plants. Therefore, the use of dry towers for geothermal power results in a greater percentage penalty on an efficiency basis.

\subsubsection{TRW, 10 MWe, Binary Isobutane Plant $\left(380^{\circ} \mathrm{F}\right.$ Brine)}

The TRW/Rogers plant design for this geothermal source is similar to the Berkeley plant; the GEOCOST/Rogers estimate comparison is shown in Table 5-4. The comments in Section 5.1.2 of this report also apply to the TRW plant except as noted below. The agreement between total plant costs $(\sim 17 \%)$ is somewhat misleading; as in 5.1 .2 , above, there are significant differences between specific account items. 
TABLE 5-4. Comparison of TRW and GEOCOST Binary

Plant Capital Cost Estimates

\section{POWER PLANT COSTS}

\section{Account}

1.0 Power Plant

1.1 Piping and Insulation

1.2 Crane

1.3 Turbogenerator

1.5 Vapor Generato: (Boiler)

1.7 Auxiliary Heat Exchangers

1.9 Misc. Process Support Equipment

1.10 Instrumentation and Controllers

1.12 Electrical Support Equipment

$\stackrel{\leftrightarrow}{G}$

Installation Testing
$10 \mathrm{MW}$ (Gross)

8 MW (Net)
Binary/Isobutane

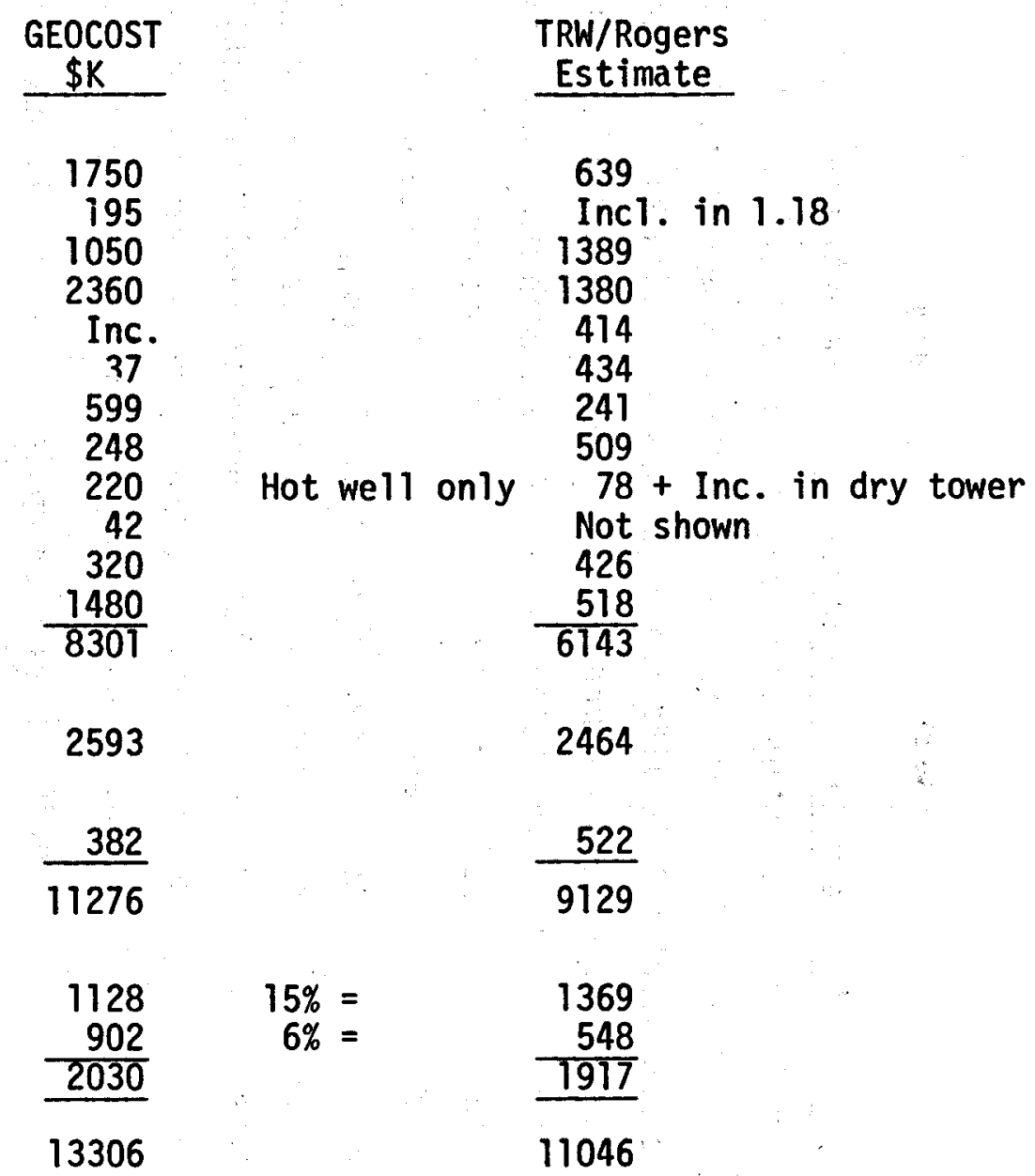

Total Power Plant Cost

1.17 Installation Testing

1.20 Pumps

1.99 Subtotal 1.0

2.0 Heat Rejection System (Cooling Towers)

2.2 Cooling Tower System, Dry

3.0 Switchyard

3.99 Subtotal

Total 1.0, 2.0, 2.0

5.0 Other Costs

5.1 Engineering and Design, PNL (10\%)

5.2 Administration and Indirect Costs, PNL (8\%)

5.99 Subtotal 5.0 
Account 1.5, Vapor Generator (Boiler): Interestingly the Vapor Generator cost as estimated by Rogers came out at $21 / 2$ the GEOCOST prediction; this differs from the fairly good agreement predicted for the LBL plant. This difference is caused by adjusting the operating condition in GEOCOST to model the economizers flow in the TRW plant, without actually simulating the use of the economizers. The extra boiler heat transfer area due to the lower geothermal fluid inlet temperature, as compared to LBL, is required to account for the increased main turbine demand in GEOCOST. Another factor which increased the boiler cost in GEOCOST, out of proportion to the heat transfer area increase, is the high pressure (and high cost) requirements of this additional heat transfer area as compared to the lower pressure, less expensive economizers used in the Roger's design.

Significant cost differences show up in Accounts 1.7, Auxiliary Heat Exchangers; 1.9, Miscellaneous Process Equipment; 1.12, Electrical Support Equipment; and 1.16, Condensers. Comments appropriate to these accounts are the same as those appearing in Section 5.1.2. The high cost of Instrumentation and Controllers, Account 1.10, in GEOCOST $\$ 599 \mathrm{~K}$ versus $\$ 247 \mathrm{~K}$ Rogers/TRW is due to an apportionment for the more costly turbine pumps and heat exchangers in GEOCOST.

Account 5.0, Other Costs: Rogers used a 21\% total multiplier for the TRW plant (same as in the Aerojet plant) rather than the $18-1 / 2 \%$ used in the LBL plant. These variations are within the expected range of these costs. $(6-4)$

\subsubsection{Bechtel Binary Geothermal Power Plant ( $380^{\circ} \mathrm{F}$ Brine)}

The Bechtel estimate ${ }^{(5-5)}$ was prepared for an Imperial Valley Site, using $380^{\circ} \mathrm{F}$ geothermal brine. A GEOCOST estimate was compared with the Bechtel design and cost estimate. Major cost differences show up in the two estimates: GEOCOST a $\$ 9955 \mathrm{~K}$ and Bechtel o $\$ 16,640 \mathrm{~K}$ (see Table 5-5). Discussion were held with the Bechtel staff in an attempt to resolve the cost differences. Equipment capacities were similar in both estimates, and conventional components have similar costs. A majority of these cost differences appear to be based on the expense for a first-of-a-kind system in the Bechtel estimate. 
TABLE 5-5. Comparison of Bechtel and GEOCOST

Binary Plant Capital Cost Estimates

TRW

$10 \mathrm{MW}$ (Net)

Binary/Isobutane

POWER PLANT CAPITAL COSTS

Account

1.0 Power Plant

1.1. Piping, Insulation, and Tanks

1.2 Crane

1.3 Turbo Generator

1.5 Vapor Generator (Boiler)

1.9 Misc. Process Support Equipment

1.10 Instrumentation and Controllers

1.12 Electrical Support Equipment

1.16 Condenser

1.17 Installation Testing

1.18 Buildings, Foundations, and Support Equipment

1.20 Binary Fluid Pumps

1.21 Reinjection Pump (Plant-located)

1.99 Subtotal 1.0

2.0 Heat Rejection System (Cooling Towers)

2.1 Cooling Tower System (Forced Draft Wet)

2.99 Subtotal 2.0

3.0 Switch Yard

3.99 Subtotal 3.0

Total 1.0, 2.0,3.0

5.0 Other Costs

5.1 Engineering and Design

5.2 Administration and Indirect Costs

5.99 Subtotal 5.0

Total Power Plant Cost

\begin{tabular}{c} 
GEOCOST \\
$\$ K$ \\
\hline 744 \\
197 \\
1395 \\
754 \\
44 \\
396 \\
126 \\
430 \\
49 \\
486 \\
2587 \\
79 \\
7287
\end{tabular}

Bechte 2738

1233

3127

260

319

1097

1221

2060

891

$\frac{--}{12946}$

$\frac{724}{724}$

637

$\overline{637}$

425

$\overline{8436}$

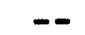

$\overline{13583}$

$\begin{array}{r}844 \\ 675 \\ \hline 1519 \\ \hline\end{array}$

3057

1519

3057

9955 
Major, unresolved cost differences show up in several equipment items, as seen in Table 5-5. For instance, Account 1.1.1 Piping, Insulation and Tanks; Accounts 1.5 and 1.16 Heat Exchangers and Condenser; and Account 1.18 Buildings, Foundations and Support Equipment runs 3 to 5 times higher in the Bechtel estimate than GEOCOST. Account 1.20 Pumps run 3 times higher in GEOCOST than the Bechtel estimate. This is due to the use of turbine pumps throughout the plant rather than a single main feed turbine pump, along with electric motor pumps for the rest of the system, used in the Bechtel design.

Account 1.12 Electrical Support Equipment is about $\$ 900 \mathrm{~K}$ higher in the Bechtel estimate. However, about $\$ 500 \mathrm{~K}$ of that is applicable to Bechtel is switchyard, Account 3.0 in GEOCOST. The turbogenerator cost estimates, Account 1.3, appear to be quite close. It also appears that Bechtel uses a $25 \%$ escalator for Other costs, Account 5.0 versus GEOCOST's $18 \%$.

Thus, the total plant cost estimates are $\$ 9955 \mathrm{~K}$ for GEOCOST and $\$ 16,640 \mathrm{~K}$ for Bechtel, a $60+\%$ difference. Resolution of these cost difference will require additional detailed study by both Bechtel and BNW. Comparison of the GEOCOST estimates with overall industry estimates including those discussed earlier, are shown in the following Section 5.1.5.

\subsubsection{Comparison of Binary Plant Cost Versus Power Level}

A data set from reference 5-3 presents TRW's estimate of binary plant costs for the East Mesa site for plants of 3, 10, 25, and 50 net MWe. Plant sizes ranging from 3 to 100 net MWe were analyzed by GEOCOST; a comparison of the TRW and GEOCOST results are shown in Figure 5-1. Two significant differences show up. First there is a large difference in projected costs, with GEOCOST being much higher and closer to the A-E estimates, also shown in Figure 5-1. Further, the slope of the two cost curves is quite different.

Reference 5-3 also provides the Rogers/TRW data point shown in the figure. These data and the Roger/LBL data are the same as analyzed in Parts 5.1.2 and 5.1.3 above. The large difference between the Rogers/TRW estimate and the TRW cost-versus-power survey points up the uncertainties plaguing the geothermal industry in this area of capital investment estimates. 


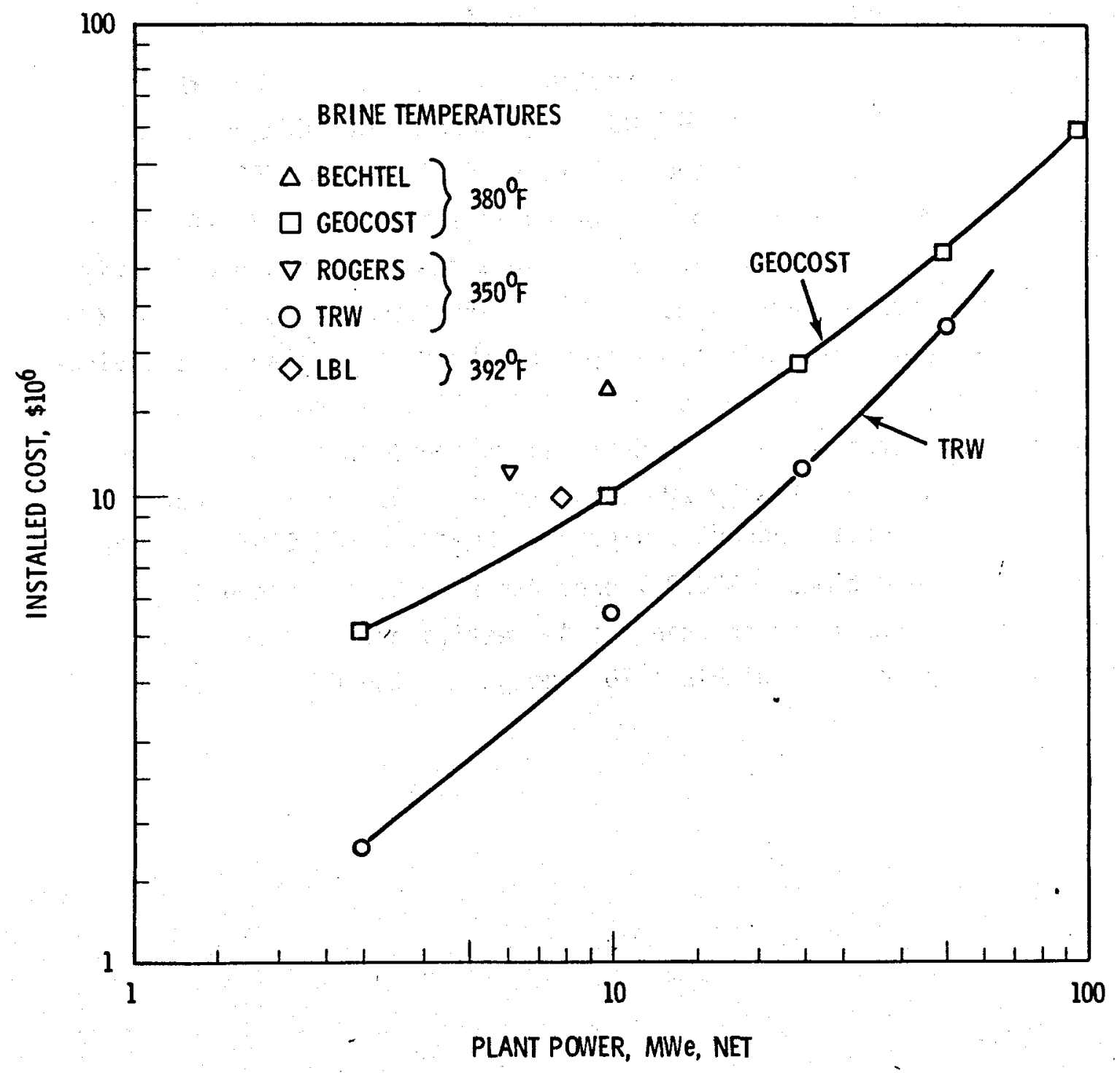

EIGÜRE 5.1-i. Comparison of GENCOST and A-E cost Estimates - Binary Plant Power Plants 
The Bechtel estimate for the Imperial Valley site, shown in Figure 5-1, helps demonstrate the wide range of projections for capital costs. The GEOCOST estimate falls in the median position among these data sets; it would be closer to the TRW/Roger and LBL costs if dry cooling towers had been used in the GEOCOST model shown in the figure.

A comparison of individual component cost variations from the A-E estimates $(5-1,-2,-3,5)$ versus GEOCOST is presented in Table 5-6. The data are presented on a percentage basis, variation from GEOCOST, and are derived from the information presented in Tables $5-1,-2,-4$ and -5 . The reader is directed to the individual sections in part 5 dealing with the specific components and plants. Table 5-6 shows a consistent $\simeq 20 \%$ in total plant cost predictions, except for the Bechtel plant. Individual component costs show some trends in the A-E - GEOCOST comparisons Account 1.10, Instrumentation and Controllers shows that GEOCOST predicts higher costs than the A-E's by $20 \%$ to a factor of 2. On the other hand, Account 1.12 Electrical Support Equipment, shows that GEOCOST underpredicts A-E costs by 2 to 8 times. GEOCOST predicts Pump Costs, Account 1.20, which are 2 to 3 times higher than the A-E estimates. Indirect costs, Account 5.0, appear to be within $\pm 10 \%$ except for the Bechtel estimate. 
TABLE 5.6. Comparison of GEOCOST and A-E Cost Estimates-A-E Estimates as a \% of GEOCOST Estimates

Account

1.1 Piping and Insulation

1.2 Crane

1.3 Turbogenerator

1.5 Vapor Generator (Boiler)

1.6 Flashers (Plant Located)

1.9 Misc. Process Support Equipment

1.10 Instrumentation and Controllers

1.12 Electrical Support Equipment

1.16 Condenser

1.17 Installation Testing

1.18 Buildings, Foundations, and Support Equipment

$\begin{array}{ll}1.20 & \text { Pumps } \\ 1.99 & \text { Subtotal } 1.0\end{array}$

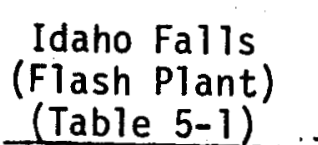

LBL
(Binary) (Table 5-2)

(a)

73

NA

68

(a)

80

(a)
94

(a)

232

30

100

2.0 Heat Rejection System (Cooling Towers)

2.2 Cooling Tower System

3.0 Swi tchyard

3.99 Subtotal

Total $1.0,2.0,3.0$

5.0 Other Costs

5.1 Engineering and Design, PNL (10\%)

5.2 Administration and Indirect

Costs, PNL (8\%)

5.99 Subtotal 5.0

Total Power Plant Cost

$\begin{array}{lrrr}52(a) & 121 & 95 & 88 \\ \text { (a) } & 112 & 137 & \text { (d) } \\ 89 & 103 & 81 & 161 \\ & & & \\ 62 & 126 & 121 & 362 \\ 158 & 77 & 61 & (d) \\ 109 & 104 & 94 & 201 \\ 92 & 103 & 83 & 167\end{array}$

Bechte 1 $($ Binary $)$
$($ Table 5-4) (Binary)
(Table 5-5)

84
(b)
149
$158(b)$
$N A$
1075
78
249
$32(b)$

(b)

37

(c)

132

$76(c)$

NA

40

205

$35(c)$

(c)

368

(d)

88

224

NA

591

81

871 (d)

284

(d)

164

35
74

424

35

177

22
97

(a)See Table 5-1; (b)See Table 5-2; (c)See Table 5-4; (d)See Table 5-5. 


\subsection{CONCLUSIONS}

These cost models were developed by separating into its major components. For the most part, independent cost models were developed based on one or more design parameters for each component. Since uncertainties in the costs of the components tend to be offsetting, the total cost is much more accurate, in a statistical sense, than the cost of the individual components.

The objective was to derive powerplant capital cost estimates for a very broad range of resource conditions, power conversion technologies, and powerplant sizes. Continuous functions were assumed throughout the entire variable range. The cost models, however, were developed from regression analyses of descrete data points. Design, material, and manufacturing constraints favor certain standard sizes and ranges of operating conditions, the cost models tend to reflect these favorable conditions. The models would tend to be less valid, and probably understate costs, for operating conditions and sizes which deviate from standard practice. A contingency provision was not included in the estimate; only identifiable costs were modeled.

The modular design of the powerplant simulation in the GEOCOST model permits the substitution of new equipment and technologies; for instance, the tube-in-shell could be replaced with a direct contact heat exchanger. The potential impact on the total cost of power can be estimated by introducing the projected performance and cost data for the new equipment. The potential impact of uncertainties in performance and cost of new technologies can be estimated in a similar manner; or conversely, economic performance and cost objectives for the new technologies can be formulated with reference to a target cost of power.

There is good agreement between GEOCOST and the reported cost for new steam plants at the Geysers. The Geysers plants show more economies to scale than the GEOCOST estimates. However, because of the limited data, it is not known whether this difference is significant or caused by factors unique to the single $110 \mathrm{MW}$ plants at the Geysers. 
There was also good agreement between GEOCOST and the total cost estimated by the AE for the one small flashed steam plant (Idaho Falls). As expected there was more variation between the two estimates in the costs of individual components, but for the most part the agreement was good. Although the opportunities to verify the cost models are limited, it is believed that these cost models will provide reasonable estimates of the total cost and the individual component costs for geothermal steam plants.

There is reasonable agreement among GEOCOST and other estimates for the total cost of binary cycle plants. GEOCOST agrees well with two AE estimates. GEOCOST was substantially $(60 \%)$ lower than the recent Bechtel estimate. There are many possible explanations for this difference, but to pinpoint the causes will require more study. GEOCOST estimates are higher than similar TRW estimates for commercial plants, but at the large plant size the TRW and GEOCOST estimates approach reasonable agreement. From this it may be concluded that the GEOCOST models will provide reasonable estimates of the potential total cost of commercial binary plants, but because of the lack of experience with binary plants, these estimates are much more uncertain than the corresponding estimates for steam plants.

Many components of the binary cycle powerplants are conventional in the sense that they are also commonly used in steam plants or in other applications. Thus, the uncertainties related to binary cycle technologies do not apply across the board, but only to parts of the plant.

There are substantial variations among GEOCOST and other estimates and among the other AE estimates themselves for specific components of the binary cycle plant. The largest variations occur in the loosely defined categories; e.g., miscellaneous support equipment, piping and insulation, etc. It is believed that the large differences result from differences in definition and classification. Resolution of these differences will require more detailed categorization and analyses of these equipment accounts.

Because of the internal consistencies built into models, such as the comparison of differential costs as between powerplant types or modifications, 
tends to be more accurate than the absolute costs. Differential cost analysis tends to eliminate bias and tends to minimize the impact of uncertainties for the common and site specific factors: Thus, even in the presence of large uncertainties in the absolute costs, differential cost analysis may reliably estimate the potential impact of alternative actions for geothermal power. 


\section{REFERENCES}

Section 1.0

1-1 C. H. Bloomster, et a]., GEOCOST: A Computer Program for Geothermal Cost Analysis, BNWL-1888, Battelle, Pacific Northwest Laboratories, Richland, WA, February 1975.

1-2 H. D. Huber, et a1., User Manual for GEOCOST: A Computer Model for Geothermal Cost Analysis, Vol. 1, Steam Cycle Version, BNWL-1942V1, Battelle, Pacific Northwest Laboratories, Richland, WA, November 1975.

1-3 H. D. Huber, et al., User Manual for GEOCOST: A Computer Model for Geotherma 1 Cost Analysis, Vol. 2, Binary Cycle Version, BNWL-1942-V2, Battelle, Pacific Northwest Laboratories, Richland, WA, March 1976.

1-4 Statistical Abstract of the United States, 1974, U.S. Department of Commerce, Social and Economics Statistics Administration, Bureau of the Census.

1-5 U.S. Bureau of the Census, Construction Reports, C-30 Series, No. 75-11, Table 6 .

Section 3.0

3-1 Pacific Gas and Electric Company Estimated Capital Cost of the Geysers Power Plant and Necessary Substation and Transmission Facilities, Public Utilities Commission, State of California, filed 1966, Units 3 and 4 .

3-2 IBID, filed 1967, Unit 5

3-3 IBID, filed 1968, Unit 6

3-4 IBID, filed 1972, Unit 11

3-5 IBID, filed 1974, Unit 13, upiated October 29, 1975.

3-6 IBID, filed 1973, Unit 14, updated September 11, 1975.

3-7 IBID, filed 1973, Unit 15. updated September 11, 1975.

3-8 "Economics of Geothermal Electric Power Generation at Matsukawa," by S. Nakamura, Geothermics (1970) Special Issue 2.

3-9 The U.S. Energy Problem, Vol. II Appendices, Part A, Intertechnology Corp., PB-207.518, November 1972. 
3-10 "Wairakei Power Station New Zealand - Economic Factors of Development and Operation," by J. H. Smith and G. R. McKenzie, Geothermics (1970) Special Issue 2.

3-11 "The Economics of the Smal1 Geothermal Power Station," by R. James, Geothermics (1970) Special Issue 2.

3-12 Magma Max Power Generating Plant Feasibility Study and Preliminary Cost Estimate, prepared for Magma Energy, Inc., by Rogers Engineering Company, San Francisco, Reco Ref. No. S-70018, September 1970.

3-13 "Cerro Prieto Cost Analys is," by Mexican Dept. of Geothermal Resources, Hot Line, Vol. 3, No. 7, December 1973.

3-14 Geothermal Power Plants, Vols. I and II, Vitro Engineering, C-56288, December 1975.

3-15 Managing Waste Heat with The Water Cooling Tower, 2nd Edition, by The Marley Company, Mission Kansas, April 1973.

3-16 Wyodak Cost Data - Internal Communication, PNL-BNW.

3-17 Telecon, Ecodyne Corporation, Cooling Tower Costs, 1974.

3-18 Cost Comparison of Dry-Type and Conventional Cooling Systems for Representative Nuclear Generating Plants, R. W. Beck and Associates, Denver, CO, March 1972, TID-26007.

3-19 Conceptual Design $10 \mathrm{MW}$ Experimental Power Generation Facility, Energy and Environment Division, Lawrence Berkeley Laboratory, September 1974.

3-20 Experimental Geothermal Research Facilities Study, Phase 0, Volumes 1 and 2, Final Report 26405-6001-RU-00, TRW for the National Science Foundation, December 1974.

3-21 General Least Squares Problem Solution with Special Reference to High-Speed Computers, R. H. Moore and R. K. Zeigler, LA-2367, October 15, 1959.

Section 4.0

4-1 Geothermal Power Plants, Vols. I and II, Vitro Engineering, C-56288, December 1975.

4-2 Optimization of Geothermal Power Plant by Use of Freon Vapour Cycle, by Valdimar K. Jonsson, A. J. Taylor, and A. D. Charmichael, TIMARIT VFi 1969. 
5-5 Electric Power Generation Using Geothermal Brine Resources for a Proof-of-Concept Facility ERDA Grant AER74-19931 A01, Submitted to Energy Research and Development Administration, Washington, DC, Bechtel Corporation, May 1975.

5-6 Paul Matthew, Geotherma ] Operating Experience at Geysers Power Plant, S cond United Nations Symposium on the Development and Use of Geothermal Resources, San Francisco, CA, 20-29 May 1975.

5-7 Geothermal Power Plants, Vol. I and II, Vitro Engineering, C-56288, Cecember 1975. 
4-3 "Magma Max Power Generating Plant Feasibility Study and Preliminary Cost Estimate," prepared for Magma Energy, Inc. by Rogers Engineering Co., San Francisco, Reco Ref. No. S-70018, September 1970.

4-4 BNW Memo, Heat Exchanger Cost Estimates, Jim Duffy to Clem Bloomster, March 25, 1975.

4-5 Letter, J. W. Tester, LASL, to P. D. Cohn, BNW March 31, 1975.

4-6 General Least Squares Problem Solution with Special Reference to High-Speed Computers, R. H. Moore and R. K. Zeigler, LA-2367, October 15, 1959.

4-7 Managing Waste Heat with the Water Cooling Tower, 2nd Edition, by The Marley Company, Mission, Kansas, April 1973.

4-8 Conceptual Design $10 \mathrm{MW}$ Experimental Power Generation Facility, September 30, 1974, Energy and Environment Division, Lawrence Berkeley Laboratory.

4-9 Experimental Geothermal Research Facilities Study, Phase 0, Vol. I and II, Final Report 26405-6001-RU-00, December 31, 1974. Prepared for the National Science Foundation by TRW.

4-10 Electric Power Generation Using Geothermal Brine Resources for a Proof-of-Concept Facility ERDA Grant AER74-19931 A01, Submitted to Energy Research and Uevelopment Administration, Washington, $D C$, Bechtel Corporation, May 1975.

Section 5.0

5-1 Capital Cost Estimate for Proposed Geothermal Power Plant Utilizing Low Salinity Geothermal Brine of $300^{\circ} \mathrm{F}$ Temperature Gross Generation $15 \mathrm{MW}$ (Nomina 1), for Aerojet Nuclear Company, Idaho Falls, ID, prepared by Rogers Engineering Co., Inc., S-74015, June 1974.

5-2 Conceptual Design $10 \mathrm{MW}$ Experimental Power Generation Facility, September 30, 1974, Energy and Environment Division, Lawrence Berkeley Laboratory.

5-3 Experimental Geothermal Research Facilities Study, Phase 0, Vol. I and II, Final Report 26405-6001-RU-00, December 31, 1974, prepared for the National Science Foundation by TRW.

5-4 The U.S. Energy Problem, Vol. II Appendices--Part A, InterTechnology Corp., November 1972, Distributed by: NTIS, U.S. Department of Commerce. 


\section{DISTRIBUTION}

No. of

Copies

\section{OFFSITE}

1 ERDA Chicago Patent Group

Energy Research \& Development Administration Argonne, IL 60439

\section{A. A. Churm}

10 Division of Geothermal Energy Energy Research \& Development Administration Washington, D.C. 20545

\section{Randall Stephens}

333 ERDA Technical Information Center

2 Electric Power Research Institute 3412 Hiliview Avenue Palo Alta, CA 94304

Phil LaMori Vasel Roberts

1 Rogers Engineering

717 Pine Street

San Francisco, CA 94111

James Kuwada

1 Stanford University

CiviT Engineering Dept.

Stanford, CA 94305

Dr. Paut Kruger

1 Chevron 0 il Company Denver, $\mathrm{CO}$

R. Greider
No. of

Copies

1 W. Ogle 3801 B West, 44th Avenue Anchorage, AK 99503

1 U.S. Department of Interior office of Geochemistry \& Geophysics

345 Middlefield Road

Menlo Park, CA 94025

L. J.P. Muffier

1 Magma Power Company P.0. Box 9 Los Altos, CA 94022

Harry W. Falk, Jr.

1 Magma Energy, Inc.

631 South Witmer Street

Los Angeles, CA $\cdot 90017$

1 Lawrence Berkeley Laboratory Berkeley, CA 94720

Kenneth F. Mirk

1 Aerojet Nuclear Company 550 Second Street Idaho Falls, ID 83401

$$
\text { Jay F. Kunze }
$$

1 Japan Geothermal Energy Association

Yurakucho Denki Bldg.

1-7-1 Yuraku-Cho Chijoda-Ku

Tokyo, Japan

1 The University of OKlahoma

School of Chemical Engineering \& Materials Science

Norman, OK 73069

Kenneth R. Starling 
No. of

Copies

1 The University of Oklahoma School of Petroleum Engineering Norman, OK 73069

Bruce Heath

1 University of Hawaii at Manoa Department of Economics

Room 542, Porteus Hall

2424 Mai1i Way

Honolulu, HI 96822

Dr. Robert Kaimins

1 ERDA Richland Operations Office
No. of

Copies

\section{ONSITE}

90 Battelle-Northwest

C. H. Bloomster (40)

J. B. Burnham

P. D. Cohn

D. E. Deonigi

R. L. Engel

J. C. Fox

J. L. Harris

H. D. Huber

W. S. Kelly

C. A. Knutsen

T. R. Kula

J. W. Litchfield

C. L. McDonald

R. W. McKee

W. R. McSpadden

R. A. Walter

S. A. Wilson

J. R. Young

Economics Library (3)

Technical Information (3)

Technical Publications 